Article

\title{
Novel Anti-Melanogenic Compounds, (Z)-5-(Substituted Benzylidene)-4-thioxothiazolidin-2-one Derivatives: In Vitro and In Silico Insights
}

\author{
Heejeong Choi ${ }^{1,+}$, Il Young Ryu ${ }^{1,+}$, Inkyu Choi ${ }^{1,+}$, Sultan Ullah ${ }^{2,+}{ }^{+}$, Hee Jin Jung ${ }^{1}$, Yujin Park ${ }^{1}$, \\ Yeongmu Jeong ${ }^{1}$, YeJi Hwang ${ }^{1}$, Sojeong Hong ${ }^{1}$, In-Soo Yoon ${ }^{1}{ }^{\circledR}$, Hwayoung Yun ${ }^{1}{ }^{1}$, Min-Soo Kim ${ }^{1}$, \\ Jin-Wook Yoo ${ }^{1} \mathbb{D}$, Yunjin Jung ${ }^{1}$, Pusoon Chun ${ }^{3,4, *}$ and Hyung Ryong Moon ${ }^{1, *(\mathbb{D})}$
}

check for updates

Citation: Choi, H.; Ryu, I.Y.; Choi, I.; Ullah, S.; Jung, H.J.; Park, Y.; Jeong, Y.; Hwang, Y.; Hong, S.; Yoon, I.-S.; et al. Novel Anti-Melanogenic Compounds, (Z)-5-(Substituted Benzylidene)-4-thioxothiazolidin-2one Derivatives: In Vitro and In Silico Insights. Molecules 2021, 26, 4963. https://doi.org/10.3390/ molecules26164963

Academic Editor: Andrzej Slominski

Received: 22 July 2021

Accepted: 12 August 2021

Published: 17 August 2021

Publisher's Note: MDPI stays neutral with regard to jurisdictional claims in published maps and institutional affiliations.

Copyright: (c) 2021 by the authors Licensee MDPI, Basel, Switzerland. This article is an open access article distributed under the terms and conditions of the Creative Commons Attribution (CC BY) license (https:/ / creativecommons.org/licenses/by/ $4.0 /)$.
1 Laboratory of Medicinal Chemistry, College of Pharmacy, Pusan National University, Busan 46241, Korea; heejeong@pusan.ac.kr (H.C.); iy102@pusan.ac.kr (I.Y.R.); godhot785@pusan.ac.kr (I.C.); hjjung2046@pusan.ac.kr (H.J.J.); pyj10@pusan.ac.kr (Y.P.); dassabn@pusan.ac.kr (Y.J.); yjw4238@pusan.ac.kr (Y.H.); wwjd0912@pusan.ac.kr (S.H.); insoo.yoon@pusan.ac.kr (I.-S.Y.); hyun@pusan.ac.kr (H.Y.); minsookim@pusan.ac.kr (M.-S.K.); jinwook@pusan.ac.kr (J.-W.Y.); jungy@pusan.ac.kr (Y.J.)

2 Department of Molecular Medicine, The Scripps Research Institute, Jupiter, FL 33458, USA; sultanwardag@gmail.com

3 College of Pharmacy, Inje University, Gyeongnam, Gimhae 50834, Korea

4 Inje Institute of Pharmaceutical Sciences and Research, Inje University, Gyeongnam, Gimhae 50834, Korea

* Correspondence: pusoon@inje.ac.kr (P.C.); mhr108@pusan.ac.kr (H.R.M.); Tel.: +82-55-320-3886 (P.C.); +82-51-510-2815 (H.R.M.); Fax: +82-55-320-3940 (P.C.); +82-51-513-6754 (H.R.M.)

$+\quad$ These authors contributed equally to this work.

Abstract: To confirm that the $\beta$-phenyl- $\alpha, \beta$-unsaturated thiocarbonyl (PUSTC) scaffold, similar to the $\beta$-phenyl- $\alpha, \beta$-unsaturated carbonyl (PUSC) scaffold, acts as a core inhibitory structure for tyrosinase, twelve (Z)-5-(substituted benzylidene)-4-thioxothiazolidin-2-one ((Z)-BTTZ) derivatives were designed and synthesized. Seven of the twelve derivatives showed stronger inhibitory activity than kojic acid against mushroom tyrosinase. Compound $2 \mathbf{b}\left(\mathrm{IC}_{50}=0.47 \pm 0.97 \mu \mathrm{M}\right)$ exerted a 141 -fold higher inhibitory potency than kojic acid. Kinetic studies' results confirmed that compounds $\mathbf{2 b}$ and $\mathbf{2 f}$ are competitive tyrosinase inhibitors, which was supported by high binding affinities with the active site of tyrosinase by docking simulation. Docking results using a human tyrosinase homology model indicated that $\mathbf{2 b}$ and $\mathbf{2} \mathbf{f}$ might potently inhibit human tyrosinase. In vitro assays of $\mathbf{2 b}$ and $\mathbf{2} \mathbf{f}$ were conducted using B16F10 melanoma cells. Compounds $\mathbf{2 b}$ and $\mathbf{2} \mathbf{f}$ significantly and concentration-dependently inhibited intracellular melanin contents, and the anti-melanogenic effects of $\mathbf{2 b}$ at $10 \mu \mathrm{M}$ and $\mathbf{2 f}$ at $25 \mu \mathrm{M}$ were considerably greater than the inhibitory effect of kojic acid at $25 \mu \mathrm{M}$. Compounds $\mathbf{2 b}$ and $\mathbf{2 f}$ similarly inhibited cellular tyrosinase activity and melanin contents, indicating that the anti-melanogenic effects of both were due to tyrosinase inhibition. A strong binding affinity with the active site of tyrosinase and potent inhibitions of mushroom tyrosinase, cellular tyrosinase activity, and melanin generation in B16F10 cells indicates the PUSTC scaffold offers an attractive platform for the development of novel tyrosinase inhibitors.

Keywords: tyrosinase; PUSTC scaffold; anti-melanogenic effect; docking simulation

\section{Introduction}

Skin whitening and depigmentation are widespread practices in some ethnic groups, especially in Asia, Africa, and the Middle East, because of the complex interplay between cultural, social, political, and psychological factors [1], and a lighter complexion is considered a beauty attribute in these regions. About $28 \%$ of the world's population undergo skin whitening at least once [2], and according to a market study, the use of skin whitening agents could reach USD 13.7 billion by 2025 [3]. In addition, depigmentation agents are also used to treat skin disorders caused by hyperpigmentation, such as 
melasma, lentigo, erythormelanosis follicularis faciei et colli, congenital melanocytic naevi, erythema dyschromicum perstans, and post-inflammatory hyperpigmentation [4]. Hyperpigmentation is the result of the excessive production of melanin, which is synthesized by melanosomes by a process called melanogenesis, which starts with the conversion of L-tyrosine to L-dopa by tyrosinase. This process occurs in special dendritic cells called melanocytes located in human skin, hair, and eyes, and at the subcellular level, is confined to unique membrane-bound organelles called melanosomes. Melanin is an essential component of the epidermis and protects skin from UV radiation and free radicals, but abnormal levels of melanin are associated with many pathologies. Tyrosinase plays a vital role in melanogenesis, as it catalyzes the rate-limiting first two stages of the process. Thus, most efforts to suppress or reduce melanogenesis in vivo have focused on the identification of tyrosinase inhibitors.

Hydroquinone, kojic acid, arbutin, azelaic acid, and resveratrol are the most commonly used skin whitening agents for cosmetic and dermatological purposes. However, these agents all raise efficacy and safety concerns. For example, hydroquinone, which is considered a gold standard and has been used for decades, can cause skin irritation, exogenous ochronosis, contact dermatitis, conjunctival melanosis, corneal degeneration, and nail discoloration when used long-term [5-8] and has toxic effects on bone marrow, the kidneys, and the immune system [9]. In addition, the hydroquinone metabolite 1,4-benzoquinone appears to be carcinogenic, which has led to a ban on the use of hydroquinone in the EU [10]. Kojic acid has storage stability issues and may be carcinogenic [11], and ellagic acid also suffers from low bioavailability problems [11]. Due to these limitations of existing tyrosinase inhibitors, researchers in academia and industry are trying to develop new, potent, safe tyrosinase inhibitors from natural and synthetic sources.

Several tyrosinase inhibitor scaffolds have been studied over the past few decades, but none of them are used clinically [12-15]. During our past studies, we synthesized various derivatives with a phenyl- $\alpha, \beta$-unsaturated carbonyl (PUSC) scaffold [16-30] with the aim of developing novel, potent tyrosinase inhibitors (Figure 1). In B16F10 melanoma cells, all of these derivatives inhibited tyrosinase and melanogenic activity more potently than kojic acid, a representative tyrosinase inhibitor. The present study was undertaken to determine whether replacing the PUSC scaffold with a $\beta$-phenyl- $\alpha, \beta$-unsaturated thiocarbonyl (PUSTC) scaffold might enhance tyrosinase inhibitory and anti-melanogenic activities (Figure 1). As 4-thioxothiazolidin-2-one has been found in many drug-like molecules [31-33] used as anticancer, antibacterial, anti-inflammatory, antiviral, and antibiotics [34-36], 4-thioxothiazolidin-2-one was considered a great template to build the PUSTC scaffold. Therefore, twelve (Z)-5-(substituted benzylidene)-4-thioxothiazolidin-2one ((Z)-BTTZ) derivatives having the 4-thioxothiazolidin-2-one structure were synthesized and evaluated for mushroom tyrosinase, B16F10 cellular tyrosinase, and melanogenesis inhibitory activities using cell-based assays. In addition, kinetic studies were conducted using Lineweaver-Burk double reciprocal plots to determine their inhibitory modes of action, and a docking simulation was performed using a homology model of human tyrosinase to investigate human tyrosinase inhibitory potentials. 


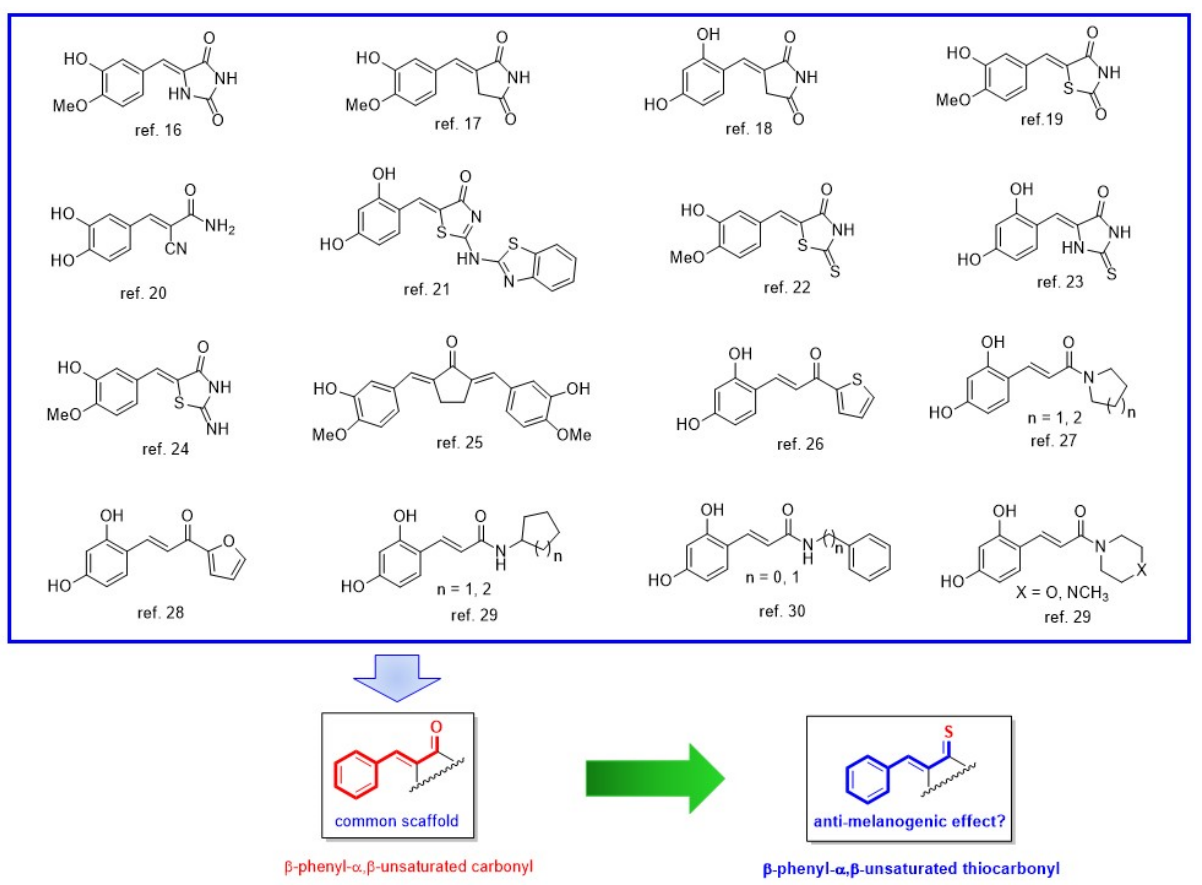

Figure 1. Potent tyrosinase inhibitors with a $\beta$-phenyl- $\alpha, \beta$-unsaturated carbonyl (PUSC) scaffold and a diagram showing the relationship between the PUSC and PUSTC scaffolds.

\section{Results and Discussion}

\subsection{Chemistry}

First, 4-thioxothiazolidin-2-one (1) was prepared as a key intermediate for the synthesis of the desired (Z)-BTTZ derivatives $\mathbf{2 a - 2 1}$ by reacting thiazolidin-2,4-dione with Lawesson's reagent (2,4-bis(4-methoxyphenyl)-2,4-dithioxo-1,3,2,4-dithiadiphosphetane) (90\% yield, Scheme 1). The synthesis of the final compounds $\mathbf{2 a - 2 1}$ was achieved using Knoevenagel condensation [37]. The coupling of compound 1 with substituted benzaldehydes in the presence of piperidine in ethanol afforded the twelve ( $Z$ )-BTTZ derivatives $\mathbf{2 a}-\mathbf{2} \mathbf{l}$ as sole products at yields from 35 to $82 \%$. To examine the effect of substituents on the $\beta$-phenyl ring of PUSTC on tyrosinase inhibition, benzaldehydes bearing a hydroxyl, methoxyl, bromo, and/or an ethoxyl group were coupled with 4-thioxothiazolidin-2-one (1). Twelve (Z)-BTTZ derivatives with the PUSTC scaffold were synthesized and identified using ${ }^{1} \mathrm{H}$ and ${ }^{13} \mathrm{C}$ NMR and mass spectroscopy. The geometries of the double bond generated by benzaldehyde coupling with compound 1 were determined using vicinal ${ }^{1} \mathrm{H}$ and ${ }^{13} \mathrm{C}$-coupling constants $\left({ }^{3} \mathrm{~J}\right)$ in proton-coupled ${ }^{13} \mathrm{C}$ NMR spectra. Nair and co-workers reported that in the proton-coupled ${ }^{13} \mathrm{C}$ NMR spectra of a variety of trisubstituted geometric isomers, which were $\alpha, \beta$-unsaturated carbonyl compounds including 5 - or 6-membered exocyclic methylene carbonyl compounds, different vicinal ${ }^{1} \mathrm{H},{ }^{13} \mathrm{C}$-coupling constants $\left({ }^{3} J\right)$ were observed (Figure 2) [38]. In geometric isomers with a cis positioned carbonyl and $\beta$-hydrogen, the carbonyl carbon had vicinal ${ }^{1} \mathrm{H},{ }^{13} \mathrm{C}$-coupling constants $\left({ }^{3} \mathrm{~J}\right)$ in the range 4.8 to $7.0 \mathrm{~Hz}$, whereas in the trans position, the carbonyl carbon had vicinal ${ }^{1} \mathrm{H}$, ${ }^{13} \mathrm{C}$-coupling constants above $10 \mathrm{~Hz}$. As shown in Figure 2, the ${ }^{13} \mathrm{C}$ NMR of compound $2 \mathbf{b}$ was measured in the proton-coupled ${ }^{13} \mathrm{C}$ mode, and the vicinal ${ }^{1} \mathrm{H},{ }^{13} \mathrm{C}$-coupling constant $\left({ }^{3} \mathrm{~J}\right)$ of $\mathrm{C} 4$ was $7.5 \mathrm{~Hz}$ (Supplementary data, S6), indicating that compound $2 \mathbf{b}$ was the (Z)-isomer. Furthermore, the ${ }^{1} \mathrm{H}$ and ${ }^{13} \mathrm{C}$ NMR data of compound $\mathbf{2} \mathbf{b}$ matched that of the authentic compound prepared by reacting compound 1 with 2,4-dihydroxybenzaldehyde in the presence of sodium acetate and acetic acid [37]. 


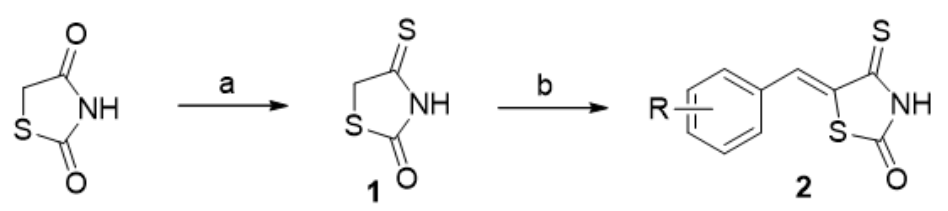

Synthesized final compounds

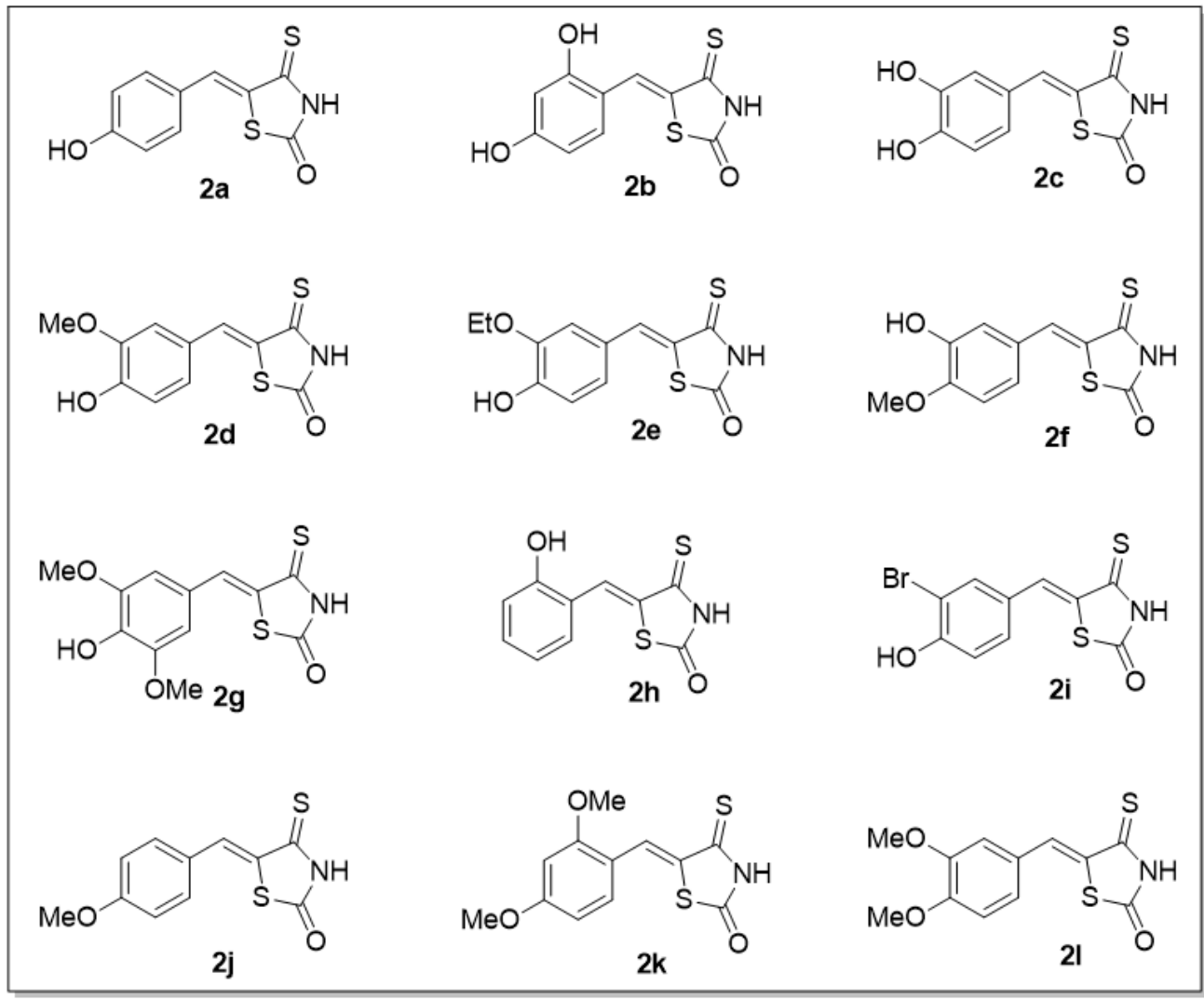

Scheme 1. Synthetic scheme for (Z)-BTTZ derivatives. Reagents and conditions: (a) Lawesson's reagent, toluene, reflux, 1 h, 90\%; (b) substituted benzaldehydes, piperidine, ethanol, reflux, 15-30 $\mathrm{min}, 35-82 \%$.<smiles>[R]C(=O)C([R])=C([R])[R]</smiles>

trisubstituted geometric isomers

${ }^{3} J=3.6-7.0 \mathrm{~Hz}$ in proton-coupled ${ }^{13} \mathrm{C}$ NMR $\quad{ }^{3} \mathrm{~J}>10 \mathrm{~Hz}$ in proton-coupled ${ }^{13} \mathrm{C}$ NMR<smiles>CCC(=C1NC(=S)NC1=O)c1ccc(O)cc1O</smiles>

${ }^{3} \mathrm{~J}=7.5 \mathrm{~Hz}$

Figure 2. Relationship between the geometry of the double bond and $\mathrm{C}, \mathrm{H}$-spin-coupling constants over three bonds and the ${ }^{3} \mathrm{~J}$ value at $\mathrm{C}(4)$ of compound $\mathbf{2 b}$.

\subsection{Mushroom Tyrosinase Inhibition and Values of Logarithm of Partition Function}

Although it has been reported that melanogenesis is regulated by hormones [39], tyrosinase inhibition is the most promising method of inhibiting melanogenesis. L-Tyrosine and L-dopa are not only substrates for melanogenesis, but also act as regulators of the melanogenesis pathway [40]. The anti-tyrosinase efficacies of the 12 synthesized (Z)BTTZ derivatives 2a-2l were examined as previously described in a study on mushroom tyrosinase inhibitory activity using kojic acid as a positive control and L-tyrosine as a substrate [39]. All 12 (Z)-BTTZ derivatives exhibited concentration-dependent mushroom tyrosinase inhibition. The $\mathrm{IC}_{50}$ values of compounds $\mathbf{2 a - 2 1}$ and kojic acid are shown in Table 1. 
Table 1. Substitution patterns and $\mathrm{IC}_{50}$ values of compounds $\mathbf{2 a}-\mathbf{2} \mathbf{l}$ and kojic acid against mushroom tyrosinase and their $\log p$ values.

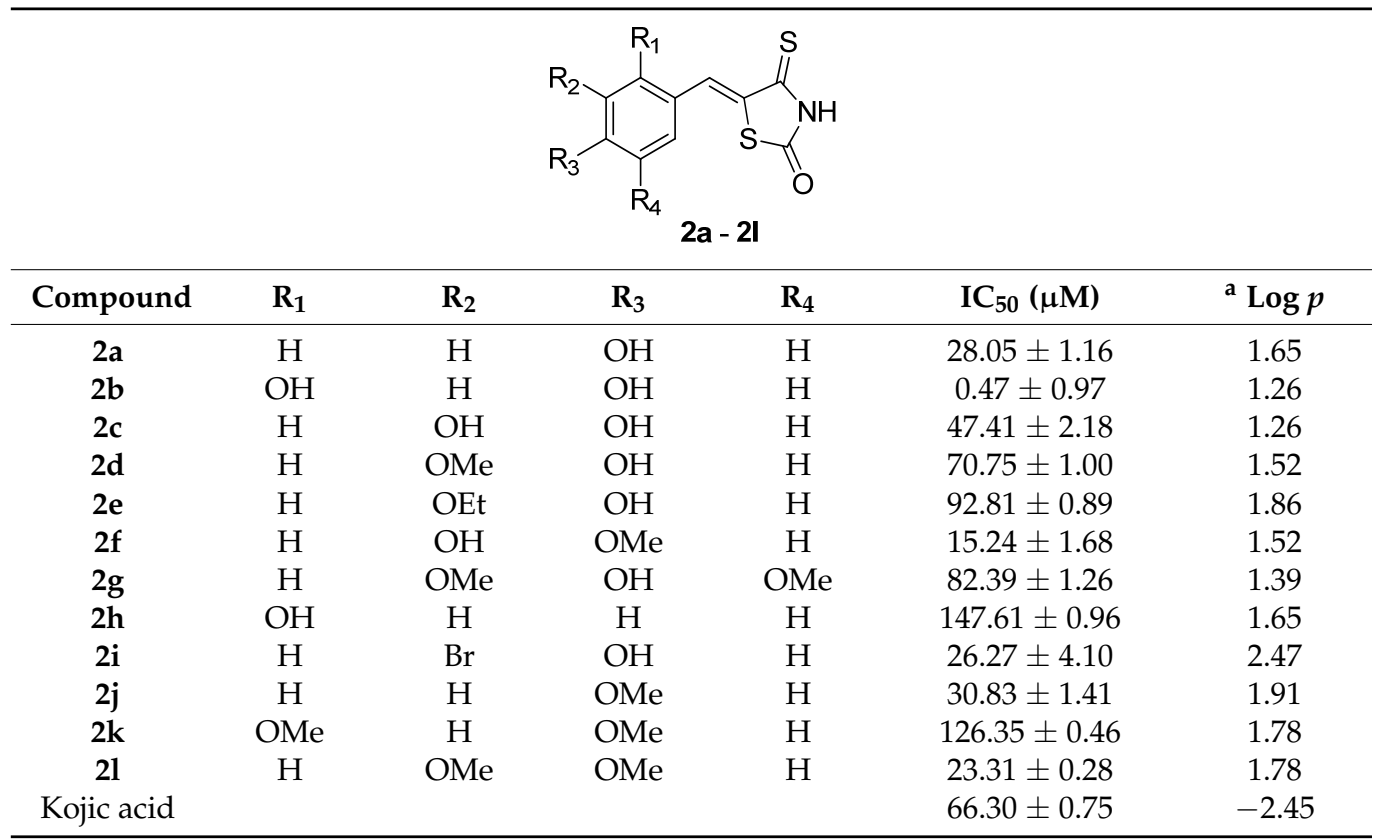

${ }^{\mathrm{a}} \log p$ values were obtained using ChemDraw Ultra 12.0.

Compound $\mathbf{2 b}$ most potently inhibited mushroom tyrosinase with an $\mathrm{IC}_{50}$ value of $0.47 \pm 0.97 \mu \mathrm{M}$, whereas the representative tyrosinase inhibitor, kojic acid, had an $\mathrm{IC}_{50}$ value of $66.30 \pm 0.75 \mu \mathrm{M}$. That is, compound $\mathbf{2 b}$ with two hydroxyls at the two and four positions on the $\beta$-phenyl ring of the PUSTC scaffold was 141 times more potent than kojic acid. Compound $\mathbf{2 f}$, which had a 3-hydroxy and a 4-methoxyl substituent on the $\beta$-phenyl ring also exhibited strong tyrosinase inhibition with an $\mathrm{IC}_{50}$ value of $15.24 \pm 1.68 \mu \mathrm{M}$. Interestingly, compound $2 \mathrm{~d}\left(\mathrm{IC}_{50}: 70.75 \pm 1.00 \mu \mathrm{M}\right)$, which had a methoxyl at the three position and a hydroxyl at the four position had a 4.6-fold lower mushroom tyrosinase inhibitory activity than compound $\mathbf{2}$ f. In addition to compounds $\mathbf{2} \mathbf{b}$ and $\mathbf{2} \mathbf{f}$, five other compounds, namely, 2a with a 4-hydroxyphenyl, 2c with a 3,4-dihydroxyphenyl, $2 \mathbf{i}$ with a 3-bromo-4-hydroxyl, 2j with a 4-methoxyl, and 21 with a 3,4-dimethoxyl, also inhibited mushroom tyrosinase more potently than kojic acid, with $\mathrm{IC}_{50}$ values of $28.05 \pm 1.16$, $47.41 \pm 2.18,26.27 \pm 4.10,30.83 \pm 1.41$, and $23.31 \pm 0.28 \mu \mathrm{M}$, respectively; that is, these five compounds had a 1.4 - to 2.8 -fold stronger tyrosinase inhibitory activity than kojic acid. Compound $\mathbf{2 e}$, in which the 3-methoxyl substituent of $\mathbf{2} \mathbf{d}$ was replaced with the more sterically demanding ethoxyl substituent, had slightly less tyrosinase inhibitory activity than kojic acid ( $\mathrm{IC}_{50}: 70.75 \pm 1.00 \mu \mathrm{M}$ to $\left.92.81 \pm 0.89 \mu \mathrm{M}\right)$. Compound $2 \mathbf{k}$, in which the 2,4-dihydroxyl substituents of compound $\mathbf{2 b}$ were replaced with 2,4-dimethoxyl, showed a dramatic reduction in tyrosinase inhibitory activity (from an $\mathrm{IC}_{50}$ of $0.47 \pm 0.97 \mu \mathrm{M}$ to $126.35 \pm 0.46 \mu \mathrm{M})$. Compound $2 \mathbf{b}$ with a 2,4-dihydroxyl substituent had the lowest $\mathrm{IC}_{50}$ value, but compounds $2 \mathbf{a}$ and $\mathbf{2 h}$ in which the 2 - or 4-hydroxyl groups of compound $\mathbf{2 b}$ were removed, respectively, had a 60- and 314-fold lower tyrosinase inhibitory activities than $\mathbf{2 b}$. These results indicate that the 2,4-dihydroxyl substitution on the $\beta$-phenyl ring of the PUSTC scaffold markedly increases tyrosinase inhibition. The insertion of a 3-bromo group into the $\beta$-phenyl ring of compound $\mathbf{2 a}$ did not affect mushroom tyrosinase inhibition (2a vs. $2 \mathbf{i}$ ). In summary, hydroxyl and methoxyl groups at $R_{3}$ conferred greater tyrosinase inhibitory activity than hydrogen, and generally, the presence of a hydroxyl group at $R_{3}$ resulted in stronger tyrosinase inhibition than a methoxyl (Figure 3). At $R_{2}$, all the substituents, including hydrogen and bromine, exhibited similar tyrosinase inhibitory activity and the presence of hydroxyl at $R_{2}$ resulted in higher tyrosinase inhibitory activity in the presence of a 4-methoxyl group ( $2 \mathbf{f}$ vs. $\mathbf{2 j}$ ). The hydroxyl substituent at $R_{1}$ greatly increased the tyrosinase inhibitory activity in the presence of the 4-hydroxyl 
substituent. These results suggest that the PUSTC scaffold might be an important template for mushroom tyrosinase inhibitors.

Inhibitory activity was dramatically increased by $\mathrm{R}_{1}=\mathrm{OH}$ in the presence of 4-hydroxyl substituent.<smiles>[Z10][Z10]1sc(=O)[nH]c1=Cc1ccc([R3])c([R])c1[R1]</smiles>

Figure 3. Structure-activity relationships of (Z)-BTTZ derivatives 2a-21.

$\log p$ values for the 12 (Z)-BTTZ derivatives 2a-21 were obtained using ChemDraw Ultra 12.0 and the observed range was 1.26 to 2.47 (Table 1 ). The $\log p$ value of kojic acid was -2.45 , which indicated that the $(Z)$-BTTZ derivatives are more likely to be absorbed by skin than kojic acid.

Due to their strong inhibitory activities against mushroom tyrosinase, compounds $\mathbf{2 b}$ and $\mathbf{2} \mathbf{f}$ were used in docking simulation and kinetic studies and in in vitro experiments on their tyrosinase inhibitory and anti-melanogenic activities.

\subsection{Modes of Action of Compounds $\mathbf{2} \mathbf{b}$ and $\mathbf{2} \mathbf{f}$}

To investigate the modes of action of compounds $\mathbf{2 b}$ and $\mathbf{2 f}$, a kinetic study was performed using mushroom tyrosinase and different concentrations of L-tyrosine as a substrate in the presence of $\mathbf{2 b}$ or $\mathbf{2} \mathbf{f}$. As depicted in Figure 4, inhibitory mechanisms were determined using Lineweaver-Burk plot analysis. The Lineweaver-Burk plot patterns of $\mathbf{2 b}$ and $\mathbf{2} \mathbf{f}$ were similar. The plots obtained at different concentrations of $\mathbf{2 b}$ and $\mathbf{2} \mathbf{f}$ merged at single points on the $y$-axis. Regardless of the concentration, the $V_{\max }$ values of $\mathbf{2} \mathbf{b}$ and $\mathbf{2} \mathbf{f}$ were independent of concentration, whereas their $K_{M}$ values increased concentration-dependently. These results show that compounds $\mathbf{2} \mathbf{b}$ and $\mathbf{2} \mathbf{f}$ are competitive inhibitors of mushroom tyrosinase.

Compound $\mathbf{2 b}$

(a)

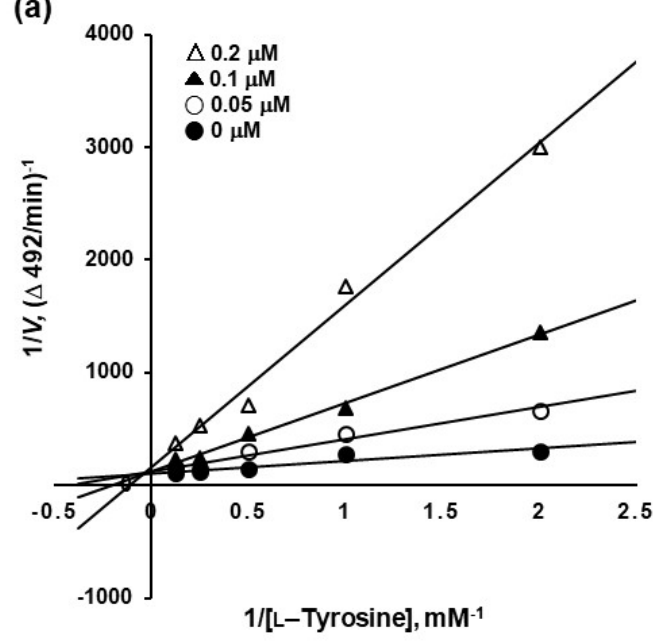

Compound $\mathbf{2 f}$

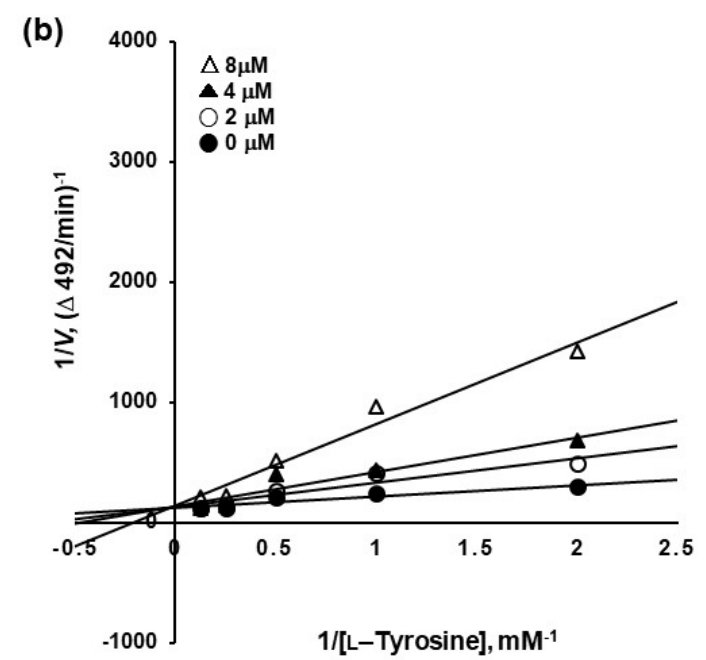

Figure 4. Lineweaver-Burk plots for the inhibition of mushroom tyrosinase by compounds (a) $2 \mathbf{b}$ and (b) $2 \mathbf{f}$. Modes of action of $\mathbf{2} \mathbf{b}$ and $\mathbf{2} \mathbf{f}$ were determined using Lineweaver-Burk plots. Results are presented as mean values of $1 / \mathrm{V}$, defined as the inverse of increased dopachrome absorbance per min at $492 \mathrm{~nm}$ as determined by three independent experiments at five different L-tyrosine concentrations. For $\mathbf{2 b}$, four different inhibitor concentrations were used, $0 \mu \mathrm{M}$ (filled circles), $0.05 \mu \mathrm{M}$ (unfilled circles), $0.1 \mu \mathrm{M}$ (filled triangles), and $0.2 \mu \mathrm{M}$ (unfilled triangles), and for $\mathbf{2 f}$, four different inhibitor concentrations were used, $0 \mu \mathrm{M}$ (filled circles), $2.0 \mu \mathrm{M}$ (unfilled circles), $4.0 \mu \mathrm{M}$ (filled triangles), and $8.0 \mu \mathrm{M}$ (unfilled triangles). The modified Michaelis-Menten equation was used to calculate $1 / \mathrm{V}_{\max }$ values $\left(1 / \mathrm{V}_{\max }=\left(1 / \mathrm{K}_{\mathrm{M}}\right)\left(1+[\mathrm{S}] / \mathrm{K}_{\mathrm{i}}\right)\right.$, where $\mathrm{V}_{\max }$ is maximum reaction rate, $K_{M}$ is a Michaelis-Menten constant, [S] is L-tyrosine concentration, and $K_{i}$ is the inhibition constant). All experiments were independently performed three times. 


\subsection{In Silico Studies of (Z)-BTTZ Derivatives $\mathbf{2} \mathbf{b}$ and $\mathbf{2} \mathbf{f}$}

In the mushroom tyrosinase enzyme assays, compounds $\mathbf{2} \mathbf{b}$ and $\mathbf{2} \mathbf{f}$ potently inhibited tyrosinase and kinetic studies indicated that they inhibited it competitively, which suggests they both bind strongly to the active site of mushroom tyrosinase. In silico studies were performed using Schrödinger Suite (release 2021-1) to determine whether tyrosinase inhibition was caused by direct binding between $\mathbf{2 b}$ or $2 \mathbf{f}$ and the active site of tyrosinase. Docking simulations of $\mathbf{2} \mathbf{b}$ and $\mathbf{2} \mathbf{f}$ were performed using the crystal structure of mushroom tyrosinase and a human tyrosinase homology model based on human tyrosinase-related protein ( $h$ TRP1). The results were compared with kojic acid.

\subsubsection{Docking Simulations of Compounds $\mathbf{2} \mathbf{b}$ and $\mathbf{2} \mathbf{f}$ and Kojic Acid with Mushroom Tyrosinase}

The crystal structure of mushroom tyrosinase (PDB ID = 2Y9X) was imported from the protein data bank (PDB) and prepared for docking against $\mathbf{2 b}, \mathbf{2} \mathbf{f}$, and kojic acid. The 2D and 3D conformations shown in Figure 5 indicate binding interactions between compounds $\mathbf{2 b}$ and $\mathbf{2} \mathbf{f}$ and the active site of mushroom tyrosinase. As shown by the figure, both compounds occupied the same binding site as kojic acid, although the interactions involved differed. Interestingly, similar to kojic acid, compound $\mathbf{2 b}$ coordinated with the copper ion (Cu401) of tyrosinase using the carbonyl of its thioxothiazolidin-2-one ring. Compound $\mathbf{2 b}$ hydrogen bonded $(2.39 \AA$ ) with Hie244 (protonated His244) instead of Met280. On the other hand, compound $2 \mathrm{f}$ did not exhibit metal coordination, but the methoxyl group of its phenyl ring interacted ( 3.37 and $4.42 \AA$ ) with both copper ions of tyrosinase. Interestingly, $\mathbf{2 f}$ and $\mathbf{2 b}$ adopted different conformations at the active site of mushroom tyrosinase. The phenyl ring of $\mathbf{2} \mathbf{b}$ was located far from the copper ions, whereas the phenyl ring of $\mathbf{2} \mathbf{f}$ was located close to the copper ions. These interactions resulted in docking scores of -5.12 and $-4.56 \mathrm{kcal} / \mathrm{mol}$ for $\mathbf{2 b}$ and $\mathbf{2 f}$, respectively, and of $-4.42 \mathrm{kcal} / \mathrm{mol}$ for kojic acid. These binding affinity scores implied that $\mathbf{2} \mathbf{b}$ and $\mathbf{2} \mathbf{f}$ inhibit mushroom tyrosinase activity more potently than kojic acid and support that both are competitive inhibitors. Furthermore, $\mathbf{2 b}$ and $\mathbf{2} \mathbf{f}$ had higher binding affinities than kojic acid, which suggested that the PUSTC scaffold, similar to the PUSC scaffold, confers potent tyrosinase inhibitory activity.
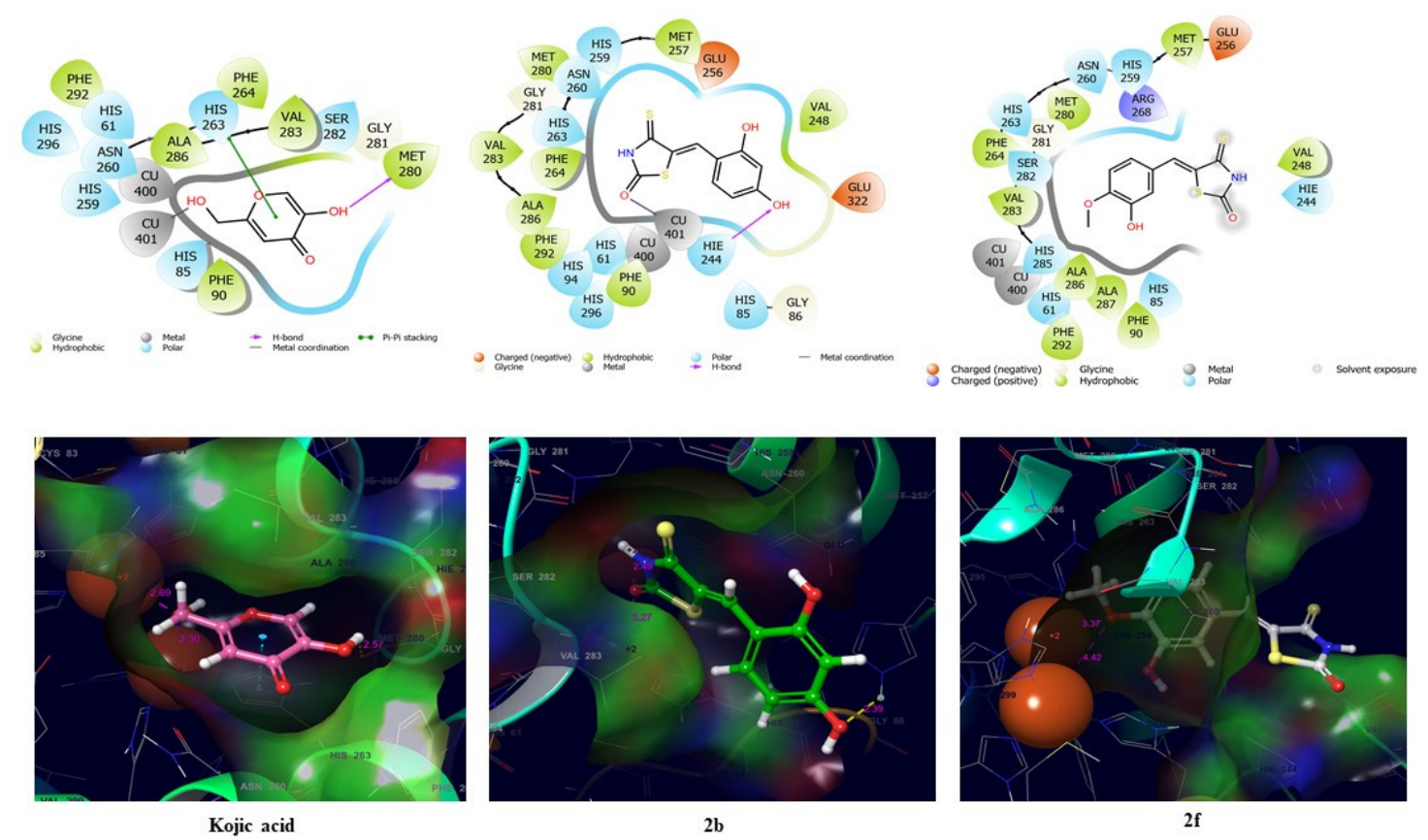

Figure 5. Docking studies on compounds $\mathbf{2 b}$ and $\mathbf{2 f}$ and kojic acid using Schrödinger Suite. mTYR (Agaricus bisporus tyrosinase, PDB ID = 2Y9X) was used as the tyrosinase for docking simulations. Pharmacophore results for $\mathbf{2 b}, \mathbf{2} \mathbf{f}$, and kojic acid are represented in $2 \mathrm{D}$ and $3 \mathrm{D}$ conformations. 
2.4.2. Docking Simulation of Compounds $\mathbf{2} \mathbf{b}$ and $\mathbf{2} \mathbf{f}$ and Kojic Acid with the Human Tyrosinase Homology Model

To further investigate the inhibitory activities of compounds $\mathbf{2} \mathbf{b}$ and $\mathbf{2 f}$, we used a human tyrosinase homology model to confirm that these compounds effectively interact with human tyrosinase. For this purpose, we created a human tyrosinase homology model using Schrödinger Suite based on human tyrosinase related protein ( $h$ TRP1, PDB ID $=5 \mathrm{M} 8 \mathrm{Q})[41,42]$.

The binding interactions between compounds $\mathbf{2 b}, \mathbf{2 f}$, and kojic acid and the human tyrosinase homology model are shown in Figure 6 in 2D and 3D conformations. Kojic acid has been shown to coordinate with a zinc ion $(\mathrm{Zn} 7)$ of tyrosinase, to form a hydrogen bond at Ser375, and to interact by pi-pi stacking with His367. Compound $\mathbf{2 b}$ was unable to coordinate with either of the two zinc ions of tyrosinase but formed two hydrogen bonds and interacted by pi-pi stacking. Compound $\mathbf{2 b}$ used one of its two hydroxyl groups on its $\beta$-phenyl ring to hydrogen bond with Ser380, and the carbonyl group of the thiooxothiazolidin-2-one ring to hydrogen bond with Gln103. Its pi-pi stacking interaction was formed by the $\beta$-phenyl ring and two amino acids, His363 and His367. The lipophilic region of compound $\mathbf{2} \mathbf{b}$ was located in a hydrophobic environment created by several amino acid residues (marked green in Figure 6). On the other hand, compound $2 f$ formed only one pi-pi stacking interaction with His202. According to these results, the calculated docking scores for compounds $\mathbf{2 b}$ and $\mathbf{2} \mathbf{f}$ and kojic acid were $-4.98,-4.05$, and $-4.56 \mathrm{kcal} / \mathrm{mol}$, respectively.

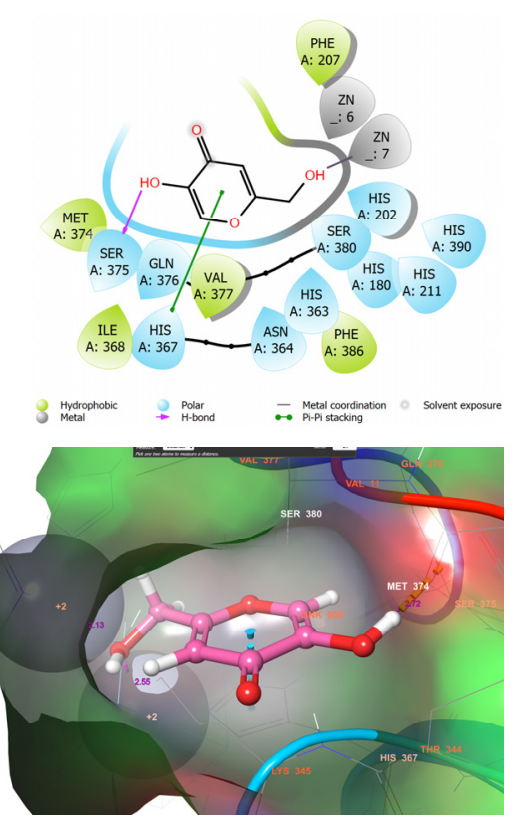

Kojic acid

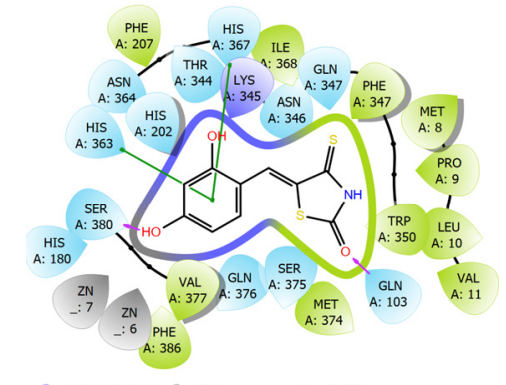

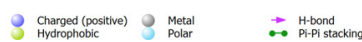

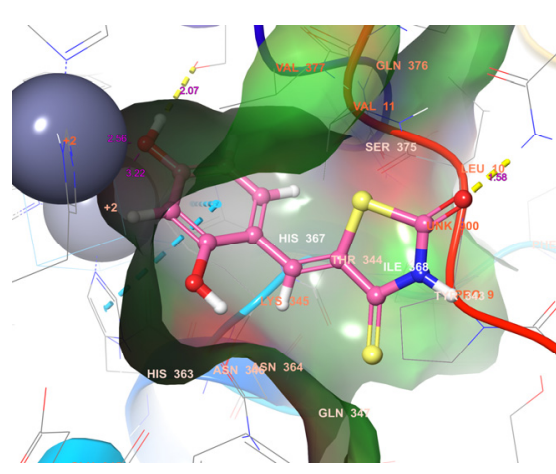

$2 \mathbf{b}$

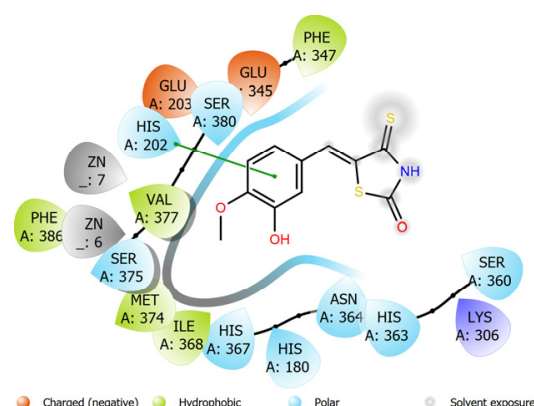

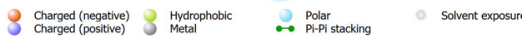

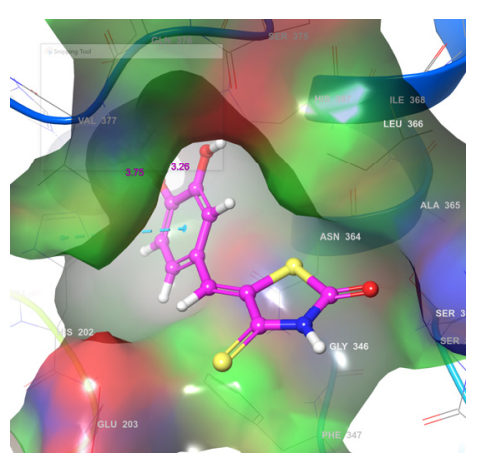

2f

Figure 6. Expected binding modes of compounds 2b, 2f, and kojic acid in the $h$ TYR homology model using Schrödinger Suite. The 2D and 3D conformations of $\mathbf{2 b}, \mathbf{2} \mathbf{f}$, and kojic acid are shown, respectively.

Compound $\mathbf{2 b}$ had a higher binding affinity than compound $\mathbf{2 f}$ or kojic acid with both $m T Y R$ and $h T Y R$ in the docking simulations. Furthermore, $\mathbf{2 b}$ and $\mathbf{2 f}$ occupied the same binding sites in $m$ TYR and $h$ TYR as kojic acid (Figures 5 and 6 ), but their interactions in the binding sites differed. The thiooxothiazolidin-2-one ring of compound $\mathbf{2 b}$ and the phenyl ring of compound $2 \mathbf{f}$ were placed near metal ions $\left(\mathrm{Cu}^{++}\right.$or $\mathrm{Zn}^{++}$, respectively) in the active sites of $m$ TYR and $h$ TYR. Both compounds had similar or higher binding affinities than 
kojic acid in docking simulations with $m$ TYR and $h$ TYR. These results indicate that the PUSTC scaffold is well tolerated at the active sites of $m$ TYR and $h$ TYR.

\subsection{Cytotoxic Effects of Compounds $\mathbf{2} \mathbf{b}$ and $\mathbf{2} \mathbf{f}$}

Before examining the inhibitory effects of compounds $\mathbf{2 b}$ and $\mathbf{2} \mathbf{f}$ on tyrosinase and melanin biosynthesis, we investigated their cytotoxic effects using murine B16F10 melanoma cells. The cells were treated with different concentrations of $\mathbf{2 b}$ or $\mathbf{2 f}(0,1,2.5,5,10$, or $25 \mu \mathrm{M}$ ) for 24 and $48 \mathrm{~h}$ (Figure 7), respectively, and the cell viabilities were assessed using the EZ-Cytox assay. Neither $\mathbf{2 b}$ nor $\mathbf{2} \mathbf{f}$ exhibited any significant cytotoxic effect at concentrations of $\leq 25 \mu \mathrm{M}$.

(a)

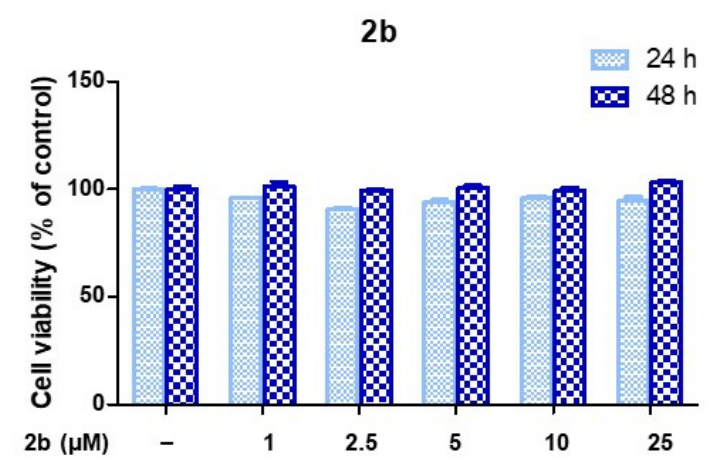

(b)

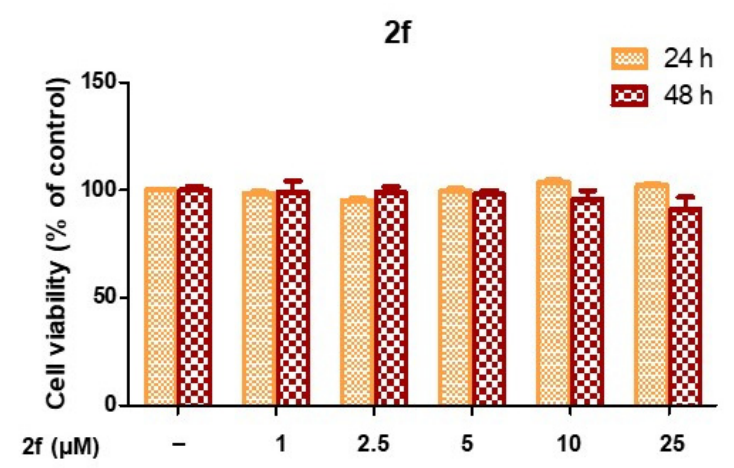

Figure 7. The cytotoxic effects of compounds $\mathbf{2 b}(\mathbf{a})$ and $\mathbf{2 f} \mathbf{f}(\mathbf{b})$ on B16F10 melanoma cells at concentrations of 1, 2.5, 5, 10, or $25 \mu \mathrm{M}$. Cell viabilities were determined using the EZ-Cytox assay and are expressed as percentages versus non-treated controls. Bars present standard errors.

\subsection{Anti-Melanogenic Activities of Compounds $\mathbf{2} \mathbf{b}$ and $\mathbf{2 f}$}

Melanin content assays were used to evaluate the inhibitory effects of compounds $\mathbf{2 b}$ and $2 \mathbf{f}$ on $\alpha$-MSH-stimulated melanogenesis. Briefly, B16F10 melanoma cells were pretreated with various concentrations $(0,5,10$, or $25 \mu \mathrm{M})$ of compounds $\mathbf{2 b}$ or $\mathbf{2 f}$ or kojic acid $(25 \mu \mathrm{M})$ for $1 \mathrm{~h}$, and then stimulated with $\alpha-\mathrm{MSH}(0.5 \mu \mathrm{M}$ for $2 \mathbf{b}$, and $1.0 \mu \mathrm{M}$ for $2 \mathrm{f})$ for $48 \mathrm{~h}$ to increase the melanin contents. The inhibitory activities on $\alpha$-MSH-stimulated melanogenesis were determined by measuring melanin optical densities.

When the $\alpha$-MSH-stimulated cells were treated with $\mathbf{2 b}$ at 5,10 , or $25 \mu \mathrm{M}$, melanin levels decreased from 1.61-fold for $\alpha$-MSH-stimulated cells to 1.19-, 0.91-, and 0.85-fold, respectively (values are percentages of non-treated controls). On the other hand, kojic acid at $25 \mu \mathrm{M}$ only decreased melanin levels to 1.38 -fold. Furthermore, $\mathbf{2 b}$ at $5 \mu \mathrm{M}$ more potently inhibited melanin production than kojic acid at $25 \mu \mathrm{M}$. When the $\alpha$-MSH-stimulated melanoma cells were treated with $\mathbf{2 b}$ at different concentrations, the reductions in melanin contents were as follows: $26 \%$ at $5 \mu \mathrm{M}, 44 \%$ at $10 \mu \mathrm{M}$, and $47 \%$ at $25 \mu \mathrm{M}$, which is compared with $14 \%$ for kojic acid at $25 \mu \mathrm{M}$ (Figure $8 \mathrm{a}$ ).

When the $\alpha$-MSH-stimulated cells were treated with $2 \mathrm{f}$ at 5,10 , or $25 \mu \mathrm{M}$, melanin levels reduced from 3.51-fold for $\alpha$-MSH $(1 \mu \mathrm{M})$ cells to 3.03-, 1.88-, and 1.42-fold, respectively (values are percentages of non-treated controls). Compound $\mathbf{2 f}$ concentration-dependently reduced melanogenesis, and at $25 \mu \mathrm{M}$, inhibited melanogenesis activity more than kojic acid $(25 \mu \mathrm{M})$. When the $\alpha$-MSH-stimulated melanoma cells were treated with $2 \mathrm{f}$, the reductions in melanin contents were $14 \%$ at $5 \mu \mathrm{M}, 46 \%$ at $10 \mu \mathrm{M}$, and $60 \%$ at $25 \mu \mathrm{M}$, which compared with $45 \%$ for kojic acid at $25 \mu \mathrm{M}$ (Figure 8 b). At $10 \mu \mathrm{M}$, compound $2 \mathrm{f}$ inhibited melanin production to the same extent as kojic acid at $25 \mu \mathrm{M}$. 
(a)

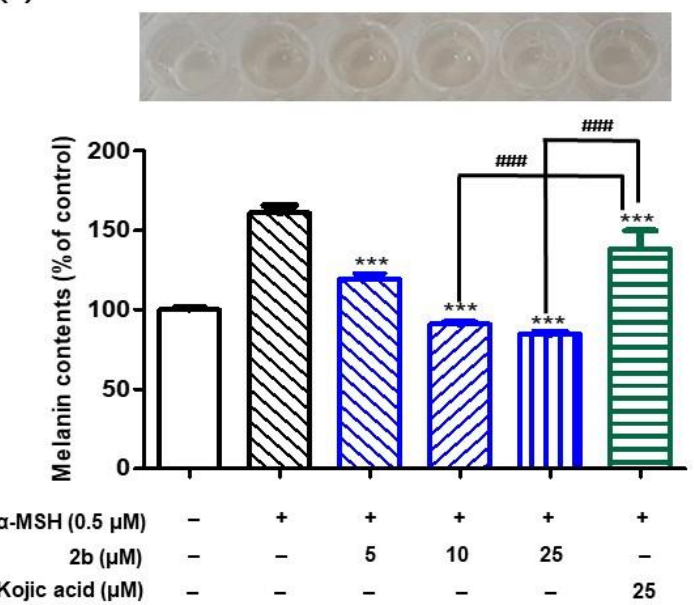

(b)
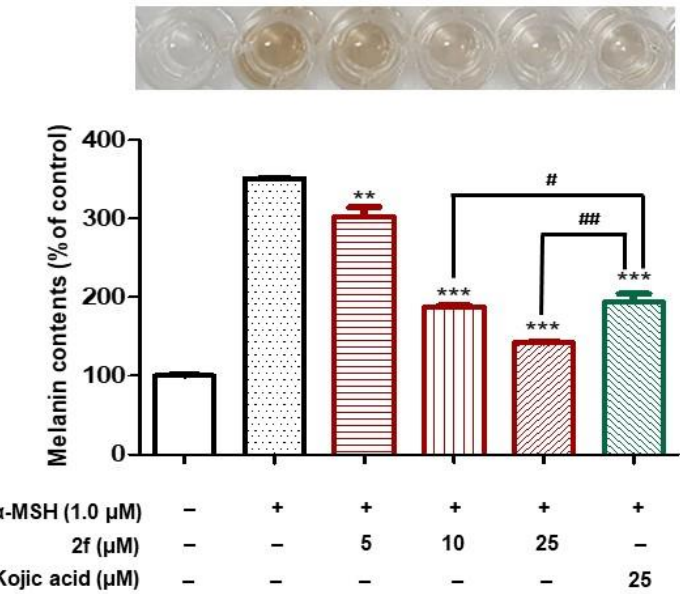

Figure 8. The effects of compounds $\mathbf{2 b}(\mathbf{a})$ and $\mathbf{2 f}(\mathbf{b})$ on melanin levels in B16F10 melanoma cells stimulated with $\alpha$-MSH $(0.5 \mu \mathrm{M}$ for $\mathbf{2 b}$, and $1.0 \mu \mathrm{M}$ for $\mathbf{2 f})$. Kojic acid was used as the positive control. B16F10 cells were treated with 5, 10, or $25 \mu \mathrm{M}$ of $\mathbf{2 b}$ or $\mathbf{2} \mathbf{f}$, or $25 \mu \mathrm{M}$ of kojic acid. Symbols ${ }^{*}$ and ${ }^{\#}$ indicate significant differences between columns: ${ }^{* *} p<0.01$, and ${ }^{* * *} p<0.001$ for $\alpha$-MSH-stimulated cells versus $\alpha$-MSH-stimulated and compound (2b, $\mathbf{2} \mathbf{f}$, or kojic acid) treated cells; ${ }^{\#} p<0.05,{ }^{\# \#} p<0.01$, and ${ }^{\# \#} p<0.001$ for compounds $\mathbf{2} \mathbf{b}$ and $\mathbf{2} \mathbf{f}$ versus kojic acid. Bars represent standard errors.

\subsection{Anti-Tyrosinase Activities of Compounds $\mathbf{2} \mathbf{b}$ and $\mathbf{2} \mathbf{f}$}

The inhibitory activities of compounds $\mathbf{2} \mathbf{b}$ and $\mathbf{2} \mathbf{f}$ against cellular tyrosinase were assessed using $\alpha$-MSH-stimulated melanoma cells. B16F10 cells were exposed to various concentrations $(0,5,10$, or $25 \mu \mathrm{M})$ of compounds $2 \mathbf{b}$ or $2 \mathbf{f}$ or kojic acid $(25 \mu \mathrm{M})$ for $1 \mathrm{~h}$, and then stimulated with $\alpha$-MSH $(0.5 \mu \mathrm{M}$ for $2 \mathbf{b}$, and $1.0 \mu \mathrm{M}$ for $2 \mathrm{f})$ for $48 \mathrm{~h}$ to increase tyrosinase activity. The inhibitory effects on tyrosinase activity were evaluated by measuring optical densities.

For compound $\mathbf{2 b}$, exposure at 5, 10, or $25 \mu \mathrm{M}$ resulted in concentration-dependent reductions in tyrosinase activity from 2.19 -fold for cells stimulated with $\alpha$-MSH (versus nontreated cells) to 1.85-, 1.48-, and 1.20-fold, respectively, which corresponded to reductions of 16,32 , and $45 \%$, as compared with $14 \%$ for $25 \mu \mathrm{M}$ kojic acid (Figure 9a). Notably, at $5 \mu \mathrm{M}, \mathbf{2 b}$ had the same inhibitory effect as kojic acid at $25 \mu \mathrm{M}$.

(a)
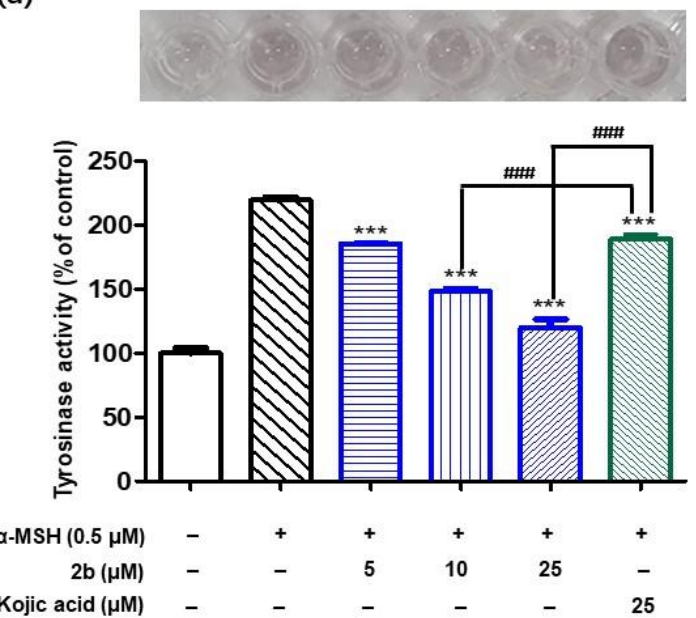

(b)
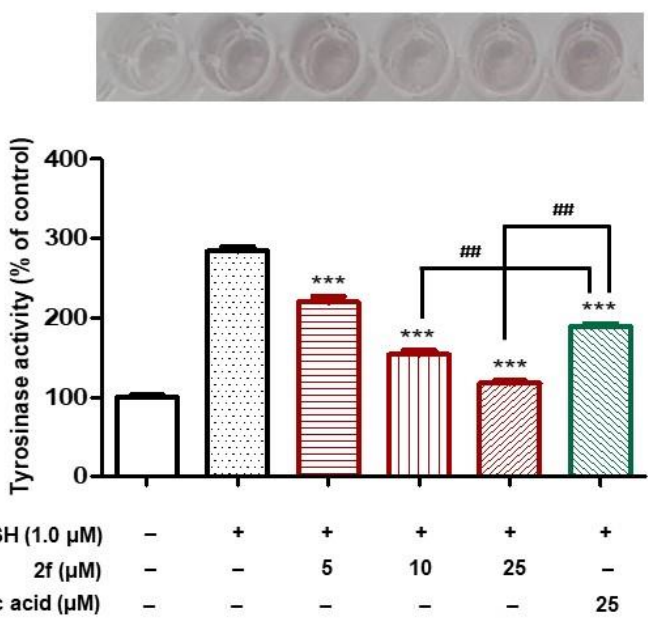

Figure 9. The inhibitory effects of compounds $\mathbf{2 b}(\mathbf{a})$ and $\mathbf{2 f}(\mathbf{b})$ on tyrosinase in B16F10 melanoma cells stimulated with $\alpha$-MSH $(0.5 \mu \mathrm{M}$ for $\mathbf{2 b}$ and $1.0 \mu \mathrm{M}$ for $\mathbf{2 f})$. Kojic acid was used as a positive control. B16F10 cells were treated with 5, 10, or $25 \mu \mathrm{M}$ of $\mathbf{2 b}$ or $\mathbf{2} \mathbf{f}$ or $25 \mu \mathrm{M}$ of kojic acid. Symbols * and ${ }^{*}$ indicate significant differences between columns: ${ }^{* * *} p<0.001$ for $\alpha$-MSH stimulated controls versus $\alpha$-MSH stimulated and $\mathbf{2 b}, \mathbf{2 f}$, or kojic acid treated cells; ${ }^{\# \#} p<0.01$ and ${ }^{\# \#} p<0.001$ for compounds $\mathbf{2} \mathbf{b}$ and $\mathbf{2} \mathbf{f}$, respectively, versus kojic acid. Bars represent standard errors. 
For compound $\mathbf{2 f}$, exposure at 5, 10, or $25 \mu \mathrm{M}$ resulted in concentration-dependent reductions in tyrosinase activity from 2.84-fold for cells stimulated with $\alpha$-MSH (versus nontreated cells) to 2.20-, 1.54-, and 1.18-fold, respectively, which corresponded to reductions of 23,46 , and $59 \%$, as compared with $33 \%$ for kojic acid at $25 \mu \mathrm{M}$. (Figure $9 \mathrm{~b}$ ).

As neither compound $\mathbf{2 b}$ nor $\mathbf{2} \mathbf{f}$ had a significant cytotoxic effect on B16F10 melanoma cells at $\leq 25 \mu \mathrm{M}$, we considered that the anti-melanogenic activities of compounds $\mathbf{2 b}$ and $\mathbf{2 f}$ (Figure 8) were caused by tyrosinase inhibition.

\section{Conclusions}

To investigate the tyrosinase inhibitory effects of the PUSTC scaffold, we synthesized 12 (Z)-BTTZ derivatives (compounds 2a to 21) with this scaffold. Seven of the derivatives inhibited mushroom tyrosinase more potently than kojic acid, and compound $\mathbf{2 b}$ had an IC $_{50}$ value of only $0.47 \pm 0.97 \mu \mathrm{M}$, which made it $>100$ times more potent than kojic acid. The Lineweaver-Burk plots of compounds $\mathbf{2 b}$ and $\mathbf{2 f}$ indicated they both competitively inhibited mushroom tyrosinase, and the docking simulation results showed both bound strongly to the active sites of human and mushroom tyrosinase. Compounds $\mathbf{2} \mathbf{b}$ and $\mathbf{2} \mathbf{f}$ inhibited tyrosinase activity concentration-dependently in $\alpha-\mathrm{MSH}$-stimulated B16F10 murine melanoma cells, and did so much more effectively than kojic acid. Melanin production was also concentration-dependently reduced by $\mathbf{2 b}$ and $\mathbf{2 f}$ in $\alpha-\mathrm{MSH}$-stimulated melanoma cells, and again both were markedly more potent than kojic acid. The similarity between the inhibitions of cellular tyrosinase and melanogenesis by compounds $\mathbf{2} \mathbf{b}$ and $\mathbf{2} \mathbf{f}$ and their minimal cytotoxic effects at $\leq 25 \mu \mathrm{M}$ suggested that their anti-melanogenic effects were due to the inhibition of cellular tyrosinase. These results suggest that the PUSTC scaffold offers a template for the design of tyrosinase inhibitors.

\section{Materials and Methods}

\subsection{Chemistry}

\subsubsection{General Methods}

All reagents were obtained commercially and used without further purification. Reactions were carried out under nitrogen and monitored using thin layer chromatography (TLC, Merck precoated $60 \mathrm{~F}_{245}$ plates). Column chromatography was conducted using MP Silica 40-63, 60 Å. All anhydrous solvents were distilled over Na/benzophenone or $\mathrm{CaH}_{2}$. Low resolution mass data were recorded in ESI positive mode on an Expression CMS mass spectrometer (Advion Inc., Ithaca, NY, USA). ${ }^{1} \mathrm{H}$ and ${ }^{13} \mathrm{C}$ NMR spectra were obtained using a Varian Unity INOVA 400 or a Varian Unity AS500 unit (Agilent technologies, Santa Clara, CA, USA) at 400 or $500 \mathrm{MHz}$ for ${ }^{1} \mathrm{H} \mathrm{NMR}$ and 100 or $125 \mathrm{MHz}$ for ${ }^{13} \mathrm{C} \mathrm{NMR}$. CD ${ }_{3} \mathrm{OD}$, $\mathrm{CDCl}_{3}$, and DMSO- $d_{6}$ were used as NMR solvents. All chemical shifts were measured in parts per million (ppm) versus residual solvent or deuterated peaks $\delta_{\mathrm{H}} 7.26$ and $\delta_{\mathrm{C}} 77.0$ for $\mathrm{CDCl}_{3}, \delta_{\mathrm{H}} 3.31$ for $\mathrm{CD}_{3} \mathrm{OD}, \delta_{\mathrm{H}} 2.48$ and $\delta_{\mathrm{C}} 40.0$ for DMSO- $\left.d_{6}\right)$. Coupling constant $(J)$ values are presented in hertz $(\mathrm{Hz})$. The following abbreviations are used for ${ }^{1} \mathrm{H}$ NMR: s (singlet), $\mathrm{d}$ (doublet), t (triplet), q (quartet), brs (broad singlet), and dd (doublet of doublets).

Synthesis of 4-thioxothiazolidin-2-one (1)

To a stirred solution of thiazolidin-2,4-dione $(7.0 \mathrm{~g}, 59.76 \mathrm{mmol})$ in toluene $(60 \mathrm{~mL})$ was added 2,4-bis(4-methoxyphenyl)-2,4-dithioxo-1,3,2,4-dithiadiphosphetane (Lawesson's reagent, $12.0 \mathrm{~g}, 29.67 \mathrm{mmol})$. The reaction mixture was refluxed for $1 \mathrm{~h}$, cooled to room temperature, and filtered. The precipitate thus obtained was washed with hexane to give 4-thioxothiazolidin-2-one (1, $7.18 \mathrm{~g}, 90 \%)$ as a solid. ${ }^{1} \mathrm{H}$ NMR (400 MHz, DMSO- $\left.d_{6}\right) \delta 4.57$ $\left(\mathrm{s}, 2 \mathrm{H}, 5-\mathrm{H}_{2}\right) ;{ }^{13} \mathrm{C}$ NMR (125 MHz, DMSO-d $\left.{ }_{6}\right) \delta 207.2(\mathrm{C}=\mathrm{S}), 176.4(\mathrm{C}=\mathrm{O}), 46.4\left(\mathrm{CH}_{2}\right)$; LRMS (ESI-) $m / z 132(\mathrm{M}-\mathrm{H})^{-}$. 
General Procedure Used to Synthesize (Z)-5-(Substituted Benzylidene)-4-thioxothiazolidin2-one Derivatives (Compounds 2a-2l)

Piperidine ( 0.3 equivalent) was added to a stirred solution of a substituted benzaldehyde (100 $\mathrm{mg}$ ) and 5,6-dihydroimidazo [2,1-b]thiazol-3(2H)-one (1.0 equivalent) in ethanol $(1.0 \mathrm{~mL})$ and refluxed for 15 to $60 \mathrm{~min}$. Water was then added to the reaction mixture and stirred overnight. The precipitate obtained by filtration was washed with water, $\mathrm{MeOH}$, DCM, ethyl acetate, and/or acetone (depending on the solubilities of residual starting materials and by-products) to give pure ( $Z$ )-5-(substituted benzylidene)-4-thioxothiazolidin2 -one derivatives $\mathbf{2} \mathbf{a}-\mathbf{2} \mathbf{1}$ as solids in yields of $35-82 \%$.

(Z)-5-(4-Hydroxybenzylidene)-4-thioxothiazolidin-2-one (Compound 2a)

Reaction time, $30 \mathrm{~min}$; yield, $49 \%$; ${ }^{1} \mathrm{H}$ NMR $\left(500 \mathrm{MHz}\right.$, DMSO- $\left.d_{6}\right) \delta 13.66$ (brs, $1 \mathrm{H}$, $\mathrm{NH}), 10.51(\mathrm{~s}, 1 \mathrm{H}, \mathrm{OH}), 8.02(\mathrm{~s}, 1 \mathrm{H}$, vinylic $\mathrm{H}), 7.54(\mathrm{~d}, 2 \mathrm{H}, J=8.5 \mathrm{~Hz}, 2-\mathrm{H}, 6-\mathrm{H}), 6.92(\mathrm{~d}$, $2 \mathrm{H}, J=8.5 \mathrm{~Hz}, 3-\mathrm{H}, 5-\mathrm{H}) ;{ }^{13} \mathrm{C}$ NMR $\left(125 \mathrm{MHz}, \mathrm{DMSO}-d_{6}\right) \delta 195.4,171.1,161.2,137.4,133.8$, 126.3, 124.9, 117.1; LRMS (ESI-) $m / z 236(\mathrm{M}-\mathrm{H})^{-}$.

(Z)-5-(2,4-Dihydroxybenzylidene)-4-thioxothiazolidin-2-one (Compound 2b)

Reaction time, $35 \mathrm{~min}$; yield, $71 \% ;{ }^{1} \mathrm{H}$ NMR $\left(500 \mathrm{MHz}, \mathrm{CD}_{3} \mathrm{OD}\right) \delta 8.62(\mathrm{~s}, 1 \mathrm{H}$, vinylic $\mathrm{H}), 7.32(\mathrm{~d}, 1 \mathrm{H}, J=8.5 \mathrm{~Hz}, 6-\mathrm{H}), 6.40(\mathrm{dd}, 1 \mathrm{H}, J=8.5,2.0 \mathrm{~Hz}, 5-\mathrm{H}), 6.36(\mathrm{~d}, 1 \mathrm{H}, J=2.0 \mathrm{~Hz}$, $3-\mathrm{H}) ;{ }^{13} \mathrm{C}$ NMR (100 MHz, DMSO-d $\left.{ }_{6}\right) \delta 195.2,171.5,163.4,161.6,133.4,130.8,124.5,113.5$, 109.6, 103.2; LRMS (ESI-) $m / z 252(\mathrm{M}-\mathrm{H})^{-}$.

(Z)-5-(3,4-Dihydroxybenzylidene)-4-thioxothiazolidin-2-one (Compound 2c)

Reaction time, 15 min; yield, $82 \% ;{ }^{1} \mathrm{H}$ NMR $\left(500 \mathrm{MHz}\right.$, DMSO- $\left.d_{6}\right) \delta 13.63$ (brs, $1 \mathrm{H}$, $\mathrm{NH}), 10.07$ (brs, $1 \mathrm{H}, \mathrm{OH}), 9.55(\mathrm{~s}, 1 \mathrm{H}, \mathrm{OH}), 7.94(\mathrm{~s}, 1 \mathrm{H}$, vinylic $\mathrm{H}), 7.06^{*}(\mathrm{~s}, 1 \mathrm{H}, 2-\mathrm{H}), 7.06^{*}$ $(\mathrm{d}, 1 \mathrm{H}, J=8.5 \mathrm{~Hz}, 6-\mathrm{H}), 6.87(\mathrm{~d}, 1 \mathrm{H}, J=8.5 \mathrm{~Hz}, 5-\mathrm{H}) ;{ }^{13} \mathrm{C}$ NMR $\left(125 \mathrm{MHz}\right.$, DMSO- $\left.d_{6}\right) \delta 195.5$, 171.3, 150.2, 146.5, 137.8, 126.1, 125.9, 125.3, 117.0, 117.0; LRMS (ESI-) $m / z 252(\mathrm{M}-\mathrm{H})^{-}$.

(Z)-5-(4-Hydroxy-3-methoxybenzylidene)-4-thioxothiazolidin-2-one (compound 2d)

Reaction time, $15 \mathrm{~min}$; yield, 53\%; ${ }^{1} \mathrm{H}$ NMR ( $500 \mathrm{MHz}$, DMSO- $\left.d_{6}\right) \delta 13.67$ (brs, $1 \mathrm{H}$, $\mathrm{NH}), 10.18(\mathrm{~s}, 1 \mathrm{H}, \mathrm{OH}), 8.04(\mathrm{~s}, 1 \mathrm{H}$, vinylic $\mathrm{H}), 7.22(\mathrm{~s}, 1 \mathrm{H}, 2-\mathrm{H}), 7.17(\mathrm{~d}, 1 \mathrm{H}, J=8.0 \mathrm{~Hz}$, $6-\mathrm{H}), 6.93(\mathrm{~d}, 1 \mathrm{H}, J=8.0 \mathrm{~Hz}, 5-\mathrm{H}), 3.82\left(\mathrm{~s}, 3 \mathrm{H}, \mathrm{OCH}_{3}\right) ;{ }^{13} \mathrm{C}$ NMR $\left(100 \mathrm{MHz}, \mathrm{DMSO}-d_{6}\right)$ $\delta$ 195.6, 171.4, 151.1, 148.8, 138.0, 126.7, 125.8, 125.6, 117.1, 115.4, 56.3; LRMS (ESI-) $m / z$ $266(\mathrm{M}-\mathrm{H})^{-}$.

(Z)-5-(3-Ethoxy-4-hydroxybenzylidene)-4-thioxothiazolidin-2-one (Compound 2e)

Reaction time, $15 \mathrm{~min}$; yield, $72 \% ;{ }^{1} \mathrm{H}$ NMR $\left(500 \mathrm{MHz}, \mathrm{CDCl}_{3}\right) \delta 9.57(\mathrm{~s}, 1 \mathrm{H}, \mathrm{NH}), 8.11$ (s, $1 \mathrm{H}$, vinylic $\mathrm{H}), 7.18(\mathrm{~d}, 1 \mathrm{H}, J=8.5 \mathrm{~Hz}, 6-\mathrm{H}), 7.06(\mathrm{~s}, 1 \mathrm{H}, 2-\mathrm{H}), 7.02(\mathrm{~d}, 1 \mathrm{H}, J=8.5 \mathrm{~Hz}$, $5-\mathrm{H}), 6.16$ (brs, $1 \mathrm{H}, \mathrm{OH}), 4.19\left(\mathrm{q}, 2 \mathrm{H}, J=7.0 \mathrm{~Hz}, \mathrm{CH}_{2} \mathrm{CH}_{3}\right), 1.51\left(\mathrm{t}, 3 \mathrm{H}, J=7.0 \mathrm{~Hz}, \mathrm{CH}_{2} \mathrm{CH}_{3}\right)$; ${ }^{13} \mathrm{C}$ NMR (100 MHz, DMSO-d $\left.d_{6}\right) \delta 193.3,169.7,149.3,146.5,138.8,126.5,126.5,126.5,115.6$, 113.4, 65.0, 14.9; LRMS (ESI-) $m / z 280(\mathrm{M}-\mathrm{H})^{-}$.

(Z)-5-(3-Hydroxy-4-methoxybenzylidene)-4-thioxothiazolidin-2-one (Compound 2f)

Reaction time, $15 \mathrm{~min}$; yield, $61 \%$; ${ }^{1} \mathrm{H}$ NMR $\left(500 \mathrm{MHz}\right.$, DMSO- $\left.d_{6}\right) \delta 13.70$ (brs, $1 \mathrm{H}$, $\mathrm{NH}), 9.58(\mathrm{~s}, 1 \mathrm{H}, \mathrm{OH}), 7.96(\mathrm{~s}, 1 \mathrm{H}$, vinylic $\mathrm{H}), 7.17(\mathrm{~d}, 1 \mathrm{H}, J=8.5 \mathrm{~Hz}, 6-\mathrm{H}), 7.08^{*}(\mathrm{~s}, 1 \mathrm{H}$, $2-\mathrm{H}), 7.07^{*}(\mathrm{~d}, 1 \mathrm{H}, J=8.5 \mathrm{~Hz}, 5-\mathrm{H}), 3.83\left(\mathrm{~s}, 3 \mathrm{H}, \mathrm{OCH}_{3}\right) ;{ }^{13} \mathrm{C}$ NMR (100 MHz, DMSO-d $\left.d_{6}\right)$ $\delta$ 195.7, 171.4, 151.5, 147.8, 137.5, 127.4, 126.8, 125.6, 116.6, 113.3, 56.4; LRMS (ESI-) $m / z$ $266(\mathrm{M}-\mathrm{H})^{-}$.

(Z)-5-(4-Hydroxy-3,5-dimethoxybenzylidene)-4-thioxothiazolidin-2-one (Compound 2g)

Reaction time, $20 \mathrm{~min}$; yield, $47 \% ;{ }^{1} \mathrm{H}$ NMR (400 MHz, DMSO- $\left.d_{6}\right) \delta 9.53$ (brs, $1 \mathrm{H}, \mathrm{OH}$ ), 8.00 (s, $1 \mathrm{H}$, vinylic $\mathrm{H}), 6.93(\mathrm{~s}, 2 \mathrm{H}, 2-\mathrm{H}, 6-\mathrm{H}), 3.79\left(\mathrm{~s}, 6 \mathrm{H}, 2 \times \mathrm{OCH}_{3}\right) ;{ }^{13} \mathrm{C} \mathrm{NMR}(100 \mathrm{MHz}$, DMSO- $d_{6}$ ) $\delta 196.4,171.9,148.9,140.1,137.7,127.8,124.6,109.3,56.8$; LRMS (ESI-) $m / z 296$ $(\mathrm{M}-\mathrm{H})^{-}$. 
(Z)-5-(2-Hydroxybenzylidene)-4-thioxothiazolidin-2-one (Compound 2h)

Reaction time, $20 \mathrm{~min}$; yield, $78 \%$; ${ }^{1} \mathrm{H}$ NMR $\left(500 \mathrm{MHz}, \mathrm{DMSO}-d_{6}\right) \delta 13.72$ (brs, $1 \mathrm{H}$, $\mathrm{NH}), 10.60(\mathrm{~s}, 1 \mathrm{H}, \mathrm{OH}), 8.44(\mathrm{~s}, 1 \mathrm{H}$, vinylic $\mathrm{H}), 7.40(\mathrm{~d}, 1 \mathrm{H}, J=8.0 \mathrm{~Hz}, 6-\mathrm{H}), 7.32(\mathrm{t}, 1 \mathrm{H}$, $J=8.0 \mathrm{~Hz}, 4-\mathrm{H}), 6.96^{*}(\mathrm{~d}, 1 \mathrm{H}, J=8.0 \mathrm{~Hz}, 3-\mathrm{H}), 6.93^{*}(\mathrm{t}, 1 \mathrm{H}, J=8.0 \mathrm{~Hz}, 5-\mathrm{H}) ;{ }^{13} \mathrm{C} \mathrm{NMR}$ $\left(100 \mathrm{MHz}, \mathrm{DMSO}-d_{6}\right) \delta 196.9,171.9,158.9,133.5,132.0,129.5,128.9,121.4,120.5,116.9$; LRMS (ESI-) $m / z 236(\mathrm{M}-\mathrm{H})^{-}$.

(Z)-5-(3-Bromo-4-hydroxybenzylidene)-4-thioxothiazolidin-2-one (Compound 2i)

Reaction time, $1 \mathrm{~h}$; yield, $73 \%$; ${ }^{1} \mathrm{H}$ NMR $\left(500 \mathrm{MHz}\right.$, DMSO- $\left.d_{6}\right) \delta 13.72$ (brs, $\left.1 \mathrm{H}, \mathrm{NH}\right)$, 11.32 (brs, $1 \mathrm{H}, \mathrm{OH}), 7.98(\mathrm{~s}, 1 \mathrm{H}$, vinylic $\mathrm{H}), 7.85(\mathrm{~s}, 1 \mathrm{H}, 2-\mathrm{H}), 7.53(\mathrm{~d}, 1 \mathrm{H}, J=8.5 \mathrm{~Hz}, 6-\mathrm{H})$, $7.09(\mathrm{~d}, 1 \mathrm{H}, J=8.5 \mathrm{~Hz}, 5-\mathrm{H}) ;{ }^{13} \mathrm{C}$ NMR $\left(100 \mathrm{MHz}, \mathrm{DMSO}-d_{6}\right) \delta$ 195.7, 171.1, 157.6, 136.7, 135.8, 132.0, 128.0, 126.8, 117.7, 111.1; LRMS (ESI-) $m / z 314(\mathrm{M}-\mathrm{H})^{-}, 316(\mathrm{M}-\mathrm{H}+2)^{-}$.

(Z)-5-(4-Methoxybenzylidene)-4-thioxothiazolidin-2-one (Compound 2j)

Reaction time, $15 \mathrm{~min}$; yield, $47 \%$; ${ }^{1} \mathrm{H}$ NMR $\left(500 \mathrm{MHz}\right.$, DMSO- $\left.d_{6}\right) \delta 13.70$ (brs, $1 \mathrm{H}$, $\mathrm{NH}), 8.05(\mathrm{~s}, 1 \mathrm{H}$, vinylic $\mathrm{H}), 7.62(\mathrm{~d}, 2 \mathrm{H}, J=8.5 \mathrm{~Hz}, 2-\mathrm{H}, 6-\mathrm{H}), 7.09(\mathrm{~d}, 2 \mathrm{H}, J=8.5 \mathrm{~Hz}, 3-\mathrm{H}$, $5-\mathrm{H}), 3.82\left(\mathrm{~s}, 3 \mathrm{H}, \mathrm{OCH}_{3}\right) ;{ }^{13} \mathrm{C}$ NMR $\left(100 \mathrm{MHz}\right.$, DMSO- $\left.d_{6}\right) \delta 196.0,171.4,162.2,136.9,133.5$, $127.8,126.7,115.8,56.3$; LRMS (ESI-) $m / z 250(\mathrm{M}-\mathrm{H})^{-}$.

\section{(Z)-5-(2,4-Dimethoxybenzylidene)-4-thioxothiazolidin-2-one (Compound 2k)}

Reaction time, $15 \mathrm{~min}$; yield, $64 \%$; ${ }^{1} \mathrm{H}$ NMR $\left(500 \mathrm{MHz}\right.$, DMSO- $\left.d_{6}\right) \delta 13.66$ (brs, $1 \mathrm{H}$, $\mathrm{NH}), 8.37(\mathrm{~s}, 1 \mathrm{H}$, vinylic $\mathrm{H}), 7.43(\mathrm{~d}, 1 \mathrm{H}, J=8.5 \mathrm{~Hz}, 6-\mathrm{H}), 6.70^{*}(\mathrm{~d}, 1 \mathrm{H}, J=8.5 \mathrm{~Hz}, 5-\mathrm{H})$, $6.68^{*}(\mathrm{~s}, 1 \mathrm{H}, 3-\mathrm{H}), 3.89\left(\mathrm{~s}, 3 \mathrm{H}, \mathrm{OCH}_{3}\right), 3.85\left(\mathrm{~s}, 3 \mathrm{H}, \mathrm{OCH}_{3}\right) ;{ }^{13} \mathrm{C}$ NMR $\left(100 \mathrm{MHz}, \mathrm{DMSO}-d_{6}\right) \delta$ 197.0, 172.2, 164.3, 161.5, 131.2, 130.7, 128.1, 116.0, 107.5, 99.3, 56.8, 56.4; LRMS (ESI-) $m / z$ $280(\mathrm{M}-\mathrm{H})^{-}$.

(Z)-5-(3,4-Dimethoxybenzylidene)-4-thioxothiazolidin-2-one (Compound 21)

Reaction time, $20 \mathrm{~min}$; yield, 35\%; ${ }^{1} \mathrm{H}$ NMR $\left(500 \mathrm{MHz}\right.$, DMSO- $\left.d_{6}\right) \delta 13.72$ (brs, $1 \mathrm{H}$, $\mathrm{NH}), 8.06(\mathrm{~s}, 1 \mathrm{H}$, vinylic $\mathrm{H}), 7.27(\mathrm{dd}, 1 \mathrm{H}, J=8.5,2.0 \mathrm{~Hz}, 6-\mathrm{H}), 7.24(\mathrm{~d}, 1 \mathrm{H}, J=2.0 \mathrm{~Hz}, 2-\mathrm{H})$, $7.13(\mathrm{~d}, 1 \mathrm{H}, J=8.5 \mathrm{~Hz}, 5-\mathrm{H}), 3.83\left(\mathrm{~s}, 3 \mathrm{H}, \mathrm{OCH}_{3}\right), 3.81\left(\mathrm{~s}, 3 \mathrm{H}, \mathrm{OCH}_{3}\right) ;{ }^{13} \mathrm{C} \mathrm{NMR}(100 \mathrm{MHz}$, DMSO- $\left.d_{6}\right) \delta 196.0,171.5,152.1,149.7,137.3,128.0,126.9,125.3,114.3,112.9,56.5,56.3$; LRMS (ESI-) $m / z 280(\mathrm{M}-\mathrm{H})^{-}$.

\subsection{Tyrosinase Inhibition-Kinetic and In Silico Studies}

\subsubsection{Mushroom Tyrosinase Inhibition Assay}

The tyrosinase inhibitory activity assay for compounds $\mathbf{2 a} \mathbf{a} \mathbf{2} \mathbf{l}$ was performed against mushroom tyrosinase, according to a previously described method [43], with minor modifications. In brief, a 200-microliter mixture consisting of a solution $(10 \mu \mathrm{L})$ of compounds $\mathbf{2 a}-\mathbf{2 l}$ at various concentrations, a tyrosinase solution $(20 \mu \mathrm{L}, 150$ units), and a substrate solution $(170 \mu \mathrm{L})$, comprising $17.2 \mathrm{mM}$ potassium phosphate buffer and $345 \mu \mathrm{M}$ L-tyrosine solution, was added to 96 -well microplates and incubated at $37^{\circ} \mathrm{C}$ in a humidified $5 \% \mathrm{CO}_{2}$ atmosphere for $30 \mathrm{~min}$. The absorbances of dopachrome produced in each well during incubation was measured at $450 \mathrm{~nm}$ using a microplate reader (VersaMax $^{\mathrm{TM}}$, Molecular Devices, Sunnyvale, CA, USA). Kojic acid, a well-known tyrosinase inhibitor, was used as a positive control. All experiments were independently conducted 3 times. To calculate the \% inhibition of tyrosinase activity, the following formula was used: $\%$ inhibition $=[1-(\mathrm{A} / \mathrm{B}) \times 100]$, where A means the optical density of the test samples and $\mathrm{B}$ means the optical density of the non-treated control. To calculate the concentration necessary for $50 \%$ inhibition of enzyme activity $\left(\mathrm{IC}_{50}\right)$, the \% tyrosinase inhibition of each compound was obtained at 3 or more different concentrations. IC $\mathrm{I}_{50}$ values were calculated by constructing a linear regression curve showing the concentration of the (Z)-BTTZ compounds on the $x$-axis and percentage inhibition on the $y$-axis. To obtain a negative control dimethyl sulfoxide (DMSO) was added instead of the (Z)-BTTZ compounds. 


\subsubsection{Kinetic Studies on Mushroom Tyrosinase Inhibition by $\mathbf{2} \mathbf{b}$ and $\mathbf{2 f}$}

Compounds $\mathbf{2 b}$ or $\mathbf{2 f}(10 \mu \mathrm{L}$, final concentrations: $0,0.05,0.1$, or $0.2 \mu \mathrm{M}$ for $\mathbf{2 b}$ and 0 , 2,4 , or $8 \mu \mathrm{M}$ for $\mathbf{2 f}$ ) and mushroom tyrosinase solution ( $20 \mu \mathrm{L}, 150$ units) were added to the wells of a 96-well plate containing aqueous solutions $(170 \mu \mathrm{L})$ containing L-tyrosine at $0.5,1.0,2.0,4.0$, or $8.0 \mathrm{mM}$ (final concentrations), distilled water, and potassium phosphate buffer (final concentration: $14.7 \mathrm{mM}, \mathrm{pH}$ 6.5), in the ratio 10:9:10. Initial rates of dopachrome formation in reaction mixtures were calculated by measuring increases in absorbances at $492 \mathrm{~nm}\left(\Delta \mathrm{OD}_{492} / \mathrm{min}\right)$ using a microplate reader (VersaMax ${ }^{\mathrm{TM}}$, Molecular Devices, Sunnyvale, CA, USA). Maximal velocity $\left(\mathrm{V}_{\max }\right)$ and Michaelis constant $\left(\mathrm{K}_{\mathrm{M}}\right)$ were determined using Lineweaver-Burk plots obtained by plotting the inverse of reaction velocity $(1 / \mathrm{V})$ against the inverse of substrate concentration $(1 /[\mathrm{S}])$ obtained at five Ltyrosine concentrations. Modes of tyrosinase inhibition were determined using points of convergence.

4.2.3. In Silico Study of Interactions between Mushroom Tyrosinase and Compounds $\mathbf{2 b}$ and $2 \mathbf{f}$ and Kojic Acid

The in silico study was conducted using Schrödinger Suite (2021-1) with minor modifications, as previously described [44]. The crystal structure of $m$ TYR (Agaricus bisporus, PDB: 2Y9X) was downloaded from the Protein Data Bank (PDB) to Maestro12.4's Protein Preparation Wizard, and processed, and unwanted protein chains were removed. To optimize the structure, hydrogen atoms were added, water molecules $>3 \AA$ away from the enzyme were removed, and the structure was minimized. The glide grid and the active site were determined using the binding site of tropolone (a ligand of tyrosinase) obtained from PDB and the literature [45-47]. The structures of compounds $\mathbf{2} \mathbf{b}$ and $\mathbf{2} \mathbf{f}$ and kojic acid were imported into the entry list of Maestro in CDXML format. Before ligand docking, the structures of $\mathbf{2} \mathbf{b}$ and $\mathbf{2} \mathbf{f}$ and kojic acid were prepared using LigPrep. The compounds were then docked to the enzyme's glide grid using Glide from the Maestro task list [48]. Binding affinities and ligand-protein interactions were obtained using the glide extra precision (XP) method [49].

4.2.4. In Silico Study of Interactions between Compounds $\mathbf{2} \mathbf{b}$ and $\mathbf{2} \mathbf{f}$ and Kojic Acid and the Human Tyrosinase Homology Model

The $h$ TYR homology model was created using the Swiss-Model online server (https: / / swissmodel.expasy.org; accessed on 4 April 2021) and Schrödinger Suite (2020-2) using default settings. The protein sequence of $h \mathrm{TYR}$ (P14679) was imported from the UniProt database (https: / / www.uniprot.org; accessed on 4 April 2021) and the homology model was generated in the Swiss-Model online server using the TRP1 (PDB: 5M8Q) template. The model was further processed using Schrödinger Suite and validated using Schrödinger prime (a homology modeling tool in Schrödinger Suite). Compounds $\mathbf{2 b}$ and $\mathbf{2} \mathbf{f}$ and kojic acid were docked with the processed human homology model using the same protocols mentioned above for $m$ TYR docking.

\subsection{Cell Culture}

Murine melanoma B16F10 cells were obtained from the American Type Culture Collection (ATCC, Manassas, VA, USA). Fetal bovine serum (FBS), Dulbecco's modified Eagle's medium (DMEM), phosphate buffer solution (PBS), penicillin, streptomycin, and trypsin were purchased from Gibco/Thermo Fisher Scientific (Carlsbad, CA, USA). B16F10 cells were cultured in DMEM containing penicillin/streptomycin (100 IU/100 $\mu \mathrm{g} / \mathrm{mL})$ and 10\% heat-inactivated FBS in a standard humidified $5 \% \mathrm{CO}_{2}$ atmosphere at $37^{\circ} \mathrm{C}$. Cell viability, anti-tyrosinase activity, and anti-melanogenic activity experiments were conducted on these cells cultured in 24- or 96-well plates. 


\subsection{Cell Viability Assays}

Cell viability assays of compounds $\mathbf{2 b}$ and $\mathbf{2 f}$ were performed using B16F10 melanoma cells and the EZ-Cytox assay (EZ-3000, DoGenBio, Seoul, Korea), as previously described [50]. Briefly, cells were seeded at a density of $1 \times 10^{4}$ cells/well in a 96-well plate for $24 \mathrm{~h}$, and then were exposed to different concentrations $(0,1,2.5,5,10$, or $25 \mu \mathrm{M})$ of $\mathbf{2 b}$ or $\mathbf{2 f}$ and incubated at $37^{\circ} \mathrm{C}$ for 24 and $48 \mathrm{~h}$, respectively. EZ-Cytox solution $(10 \mu \mathrm{L})$ was then added to each well and cells were incubated at $37^{\circ} \mathrm{C}$ for $2 \mathrm{~h}$. Absorbances were measured at $450 \mathrm{~nm}$ using a microplate reader (VersaMax ${ }^{\mathrm{TM}}$, Molecular Devices, Sunnyvale, CA, USA). Each assay was performed in triplicate.

\subsection{Anti-Melanogenesis Activity Assays}

The anti-melanogenesis activities of compounds $\mathbf{2} \mathbf{b}$ and $\mathbf{2} \mathbf{f}$ were assessed using a standard melanin content assay with minor modifications [51]. Briefly, B16F10 cells were seeded at a density of $5 \times 10^{4}$ /well in a 24-well plate and allowed to adhere to wells in a DMEM solution containing penicillin/streptomycin (100 IU $/ 100 \mu \mathrm{g} / \mathrm{mL})$ and $10 \%$ heatinactivated FBS in a standard humidified $5 \% \mathrm{CO}_{2}$ atmosphere at $37^{\circ} \mathrm{C}$. After culture for $24 \mathrm{~h}$, cells were exposed to $\alpha$-MSH ( $0.5 \mu \mathrm{M}$ for $2 \mathbf{b}$ and $1.0 \mu \mathrm{M}$ for $\mathbf{2 f})$ and various concentrations $(0,5,10$, or $25 \mu \mathrm{M})$ of $\mathbf{2 b}$ or $\mathbf{2} \mathbf{f}$ or kojic acid at $25 \mu \mathrm{M}$ in a standard humidified $5 \% \mathrm{CO}_{2}$ atmosphere at $37^{\circ} \mathrm{C}$ for $48 \mathrm{~h}$. Cells were then rinsed twice with PBS and lysed in $200 \mu \mathrm{L}$ of $1 \mathrm{~N} \mathrm{NaOH}$ containing $10 \%$ dimethyl sulfoxide (DMSO) for $1 \mathrm{~h}$ at $60^{\circ} \mathrm{C}$. Lysates were transferred to the wells of a 96-well plate, and melanin absorbances were measured at $405 \mathrm{~nm}$ using a microplate reader (VersaMax ${ }^{\mathrm{TM}}$, Molecular Devices, Sunnyvale, CA, USA). All experiments were conducted three times in triplicate. Kojic acid, $1 \mathrm{~N} \mathrm{NaOH}$, DMSO, and $\alpha$-MSH were purchased from Sigma-Aldrich (St. Louis, MO, USA).

\subsection{Anti-Tyrosinase Activity Assays}

3,4-Dihydroxy-L-phenylalanine (L-DOPA), phenylmethylsulfonyl fluoride (PMSF), 4(1,1,3,3-tetramethylbutyl)phenylpolyethylene glycol (Triton $\left.{ }^{\mathrm{TM}} \mathrm{X}-100\right)$, potassium hydrogen phosphate, and potassium dihydrogen phosphate were purchased from Sigma-Aldrich (St. Louis, MO, USA).

Tyrosinase activities were assessed by determining the L-DOPA oxidation rate, as described previously with minor modifications [52]. Briefly, B16F10 cells were seeded at $5 \times 10^{4}$ cells/well in a 24-well plate, allowed to adhere to wells in a DMEM solution containing penicillin/streptomycin (100 IU $/ 100 \mu \mathrm{g} / \mathrm{mL}$ ) and 10\% heat-inactivated FBS in a standard humidified $5 \% \mathrm{CO}_{2}$ atmosphere at $37^{\circ} \mathrm{C}$ for $24 \mathrm{~h}$, exposed to $\alpha$-MSH $(0.5 \mu \mathrm{M}$ for $\mathbf{2 b}$ and $1.0 \mu \mathrm{M}$ for $\mathbf{2 f})$ and various concentrations $(0,5,10$, or $25 \mu \mathrm{M})$ of $2 \mathbf{b}$ or $2 \mathbf{f}$ or kojic acid $(25 \mu \mathrm{M})$, and incubated in a standard humidified $5 \% \mathrm{CO}_{2}$ atmosphere at $37^{\circ} \mathrm{C}$ for $48 \mathrm{~h}$. Cells were then rinsed twice with PBS, exposed to $100 \mu \mathrm{L}$ of lysis buffer ( $90 \mu \mathrm{L}$ of $50 \mathrm{mM}$ phosphate buffer $\mathrm{pH} 6.8 ; 5 \mu \mathrm{L}$ of $2 \mathrm{mM}$ PMSF; $5 \mu \mathrm{L}$ of $20 \%$ Triton), and frozen at $-80{ }^{\circ} \mathrm{C}$ for $30 \mathrm{~min}$. After defrosting, lysates were centrifuged at $12,000 \mathrm{~g}$ for $30 \mathrm{~min}$ at $4{ }^{\circ} \mathrm{C}$, and supernatants $(80 \mu \mathrm{L})$ were mixed with $10 \mathrm{mM} \mathrm{L}$-DOPA $(20 \mu \mathrm{L})$ in a 96-well plate. Absorbances were measured at $490 \mathrm{~nm}$ at $37^{\circ} \mathrm{C}$ every $10 \mathrm{~min}$ for $1 \mathrm{~h}$ using a microplate reader (VersaMax ${ }^{\mathrm{TM}}$, Molecular Devices, Sunnyvale, CA, USA). All experiments were carried out three times in triplicate.

\subsection{Statistical Analysis}

One-way analysis of variance (ANOVA) followed by Bonferroni post hoc test was used to determine the significances of differences between treatments. The statistical analysis was carried out using GraphPad Prism 5 software (La Jolla, CA, USA). Results are presented as means \pm standard errors of means (SEMs). Two-sided $p$-values of $<0.05$ were considered significant.

Supplementary Materials: The following are available online. ${ }^{1} \mathrm{H}$ - and ${ }^{13} \mathrm{C}$ NMR and ESI-mass data of compounds $\mathbf{1 a}$ and $\mathbf{2 a} \mathbf{- 2} \mathbf{l}$ are provided in the Supplementary Materials. 
Author Contributions: Conceptualization, P.C. and H.R.M.; data curation, Y.J. (Yeongmu Jeong); formal analysis, I.Y.R. and Y.H.; funding acquisition, P.C.; investigation, S.H.; methodology, H.C. and P.C.; resources, I.C. and H.J.J.; software, S.U. and Y.P.; supervision, H.R.M.; writing—original draft, H.R.M.; writing - review and editing, I.-S.Y., H.Y., M.-S.K., J.-W.Y. and Y.J. (Yunjin Jung), All authors have read and agreed to the published version of the manuscript.

Funding: This work was supported by a grant from Research year of Inje University in 2020 (20210001). Institutional Review Board Statement: Not applicable.

Informed Consent Statement: Not applicable.

Data Availability Statement: Data are available from the authors upon reasonable request.

Conflicts of Interest: The authors declare no competing interests.

Sample Availability: Samples of the compounds are available from the authors.

\section{References}

1. Naidoo, L.; Khoza, N.; Dlova, N.C. A Fairer Face, a Fairer Tomorrow? A Review of Skin Lighteners. Cosmetics 2016, 3, 33. [CrossRef]

2. Sagoe, D.; Pallesen, S.; Dlova, N.C.; Lartey, M.; Ezzedine, K.; Dadzie, O. The global prevalence and correlates of skin bleaching: A meta-analysis and meta-regression analysis. Int. J. Dermatol. 2019, 58, 24-44. [CrossRef] [PubMed]

3. Global Industry Analysts (GIA) Report. Available online: https://cosmetics.specialchem.com/news/industry-news/skinlightening-products-market-report-000219549 (accessed on 4 April 2021).

4. $\quad$ Maymone, M.B.C.; Neamah, H.H.; Wirya, S.A.; Patzelt, N.M.; Secemsky, E.A.; Zancanaro, P.Q.; Vashi, N.A. The impact of skin hyperpigmentation and hyperchromia on quality of life: A cross-sectional study. J. Am. Acad. Dermatol. 2017, 77, 775-778. [CrossRef]

5. Ogiwara, Y.; Sugiura, M.; Watanabe, K.; Tawara, J.; Endo, E.; Maruyama, H.; Tsuji, S.; Matsue, K.; Yamada, H.; Wako, Y. Evaluation of the repeated-dose liver, bone marrow and peripheral blood micronucleus and comet assays using kojic acid. Mutat. Res. Genet. Toxicol. Environ. Mutagen. 2015, 780, 111-116. [CrossRef]

6. Westerhof, W.; Kooyers, T. Hydroquinone and its analogues in dermatology-A potential health risk. J. Cosmet. Dermatol. 2005, 4, 55-59. [CrossRef]

7. Gaskell, M.; McLuckie, K.I.; Farmer, P.B. Genotoxicity of the benzene metabolites para-benzoquinone and hydroquinone. Chem.-Biol. Interact. 2005, 153, 267-270. [CrossRef] [PubMed]

8. Maeda, K.; Fukuda, M. Arbutin: Mechanism of its depigmenting action in human melanocyte culture. J. Pharmacol. Exp. Ther. 1996, 276, 765-769.

9. Andersen, F.A.; Bergfeld, W.F.; Belsito, D.V.; Hill, R.A.; Klaassen, C.D.; Liebler, D.C.; Marks, J.G.; Shank, R.C.; Slaga, T.J.; Snyder, P.W. Final Amended Safety Assessment of Hydroquinone as Used in Cosmetics. Int. J. Toxicol. 2010, 29, 274S-287S. [CrossRef] [PubMed]

10. Nordlund, J.; Grimes, P.; Ortonne, J. The safety of hydroquinone. J. Eur. Acad. Dermatol. Venereol. 2006, 20, 781-787. [CrossRef]

11. Pillaiyar, T.; Namasivayam, V.; Manickam, M.; Jung, S.-H. Inhibitors of Melanogenesis: An Updated Review. J. Med. Chem. 2018, 61, 7395-7418. [CrossRef]

12. Chang, T.-S. An updated review of tyrosinase inhibitors. Int. J. Mol. Sci. 2009, 10, 2440-2475. [CrossRef]

13. Zolghadri, S.; Bahrami, A.; Hassan Khan, M.T.; Munoz-Munoz, J.; Garcia-Molina, F.; Garcia-Canovas, F.; Saboury, A.A. A comprehensive review on tyrosinase inhibitors. J. Enzym. Inhib. Med. Chem. 2019, 34, 279-309. [CrossRef]

14. Ullah, S.; Son, S.; Yun, H.Y.; Kim, D.H.; Chun, P.; Moon, H.R. Tyrosinase inhibitors: A patent review (2011-2015). Expert Opin. Ther. Pat. 2016, 26, 347-362. [CrossRef]

15. Roulier, B.; Pérès, B.; Haudecoeur, R. Advances in the Design of Genuine Human Tyrosinase Inhibitors for Targeting Melanogenesis and Related Pigmentations. J. Med. Chem. 2020, 63, 13428-13443. [CrossRef]

16. Ha, Y.M.; Kim, J.-A.; Park, Y.J.; Park, D.; Kim, J.M.; Chung, K.W.; Lee, E.K.; Park, J.Y.; Lee, J.Y.; Lee, H.J. Analogs of 5-(substituted benzylidene) hydantoin as inhibitors of tyrosinase and melanin formation. Biochim. Biophys. Acta (BBA)-Gen. Subj. 2011, 1810, 612-619. [CrossRef]

17. Ha, Y.M.; Kim, J.-A.; Park, Y.J.; Park, D.; Choi, Y.J.; Kim, J.M.; Chung, K.W.; Han, Y.K.; Park, J.Y.; Lee, J.Y. Synthesis and biological activity of hydroxybenzylidenyl pyrrolidine-2, 5-dione derivatives as new potent inhibitors of tyrosinase. MedChemComm 2011, 2, 542-549. [CrossRef]

18. Chung, K.W.; Park, Y.J.; Choi, Y.J.; Park, M.H.; Ha, Y.M.; Uehara, Y.; Yoon, J.H.; Chun, P.; Moon, H.R.; Chung, H.Y. Evaluation of in vitro and in vivo anti-melanogenic activity of a newly synthesized strong tyrosinase inhibitor (E)-3-(2, 4 dihydroxybenzylidene) pyrrolidine-2, 5-dione (3-DBP). Biochim. Biophys. Acta (BBA)-Gen. Subj. 2012, 1820, 962-969. [CrossRef]

19. Ha, Y.M.; Park, Y.J.; Kim, J.-A.; Park, D.; Park, J.Y.; Lee, H.J.; Lee, J.Y.; Moon, H.R.; Chung, H.Y. Design and synthesis of 5-(substituted benzylidene) thiazolidine-2, 4-dione derivatives as novel tyrosinase inhibitors. Eur. J. Med. Chem. 2012, 49, 245-252. [CrossRef] [PubMed] 
20. Son, S.; Kim, H.; Yun, H.Y.; Ullah, S.; Kim, S.J.; Kim, Y.-J.; Kim, M.-S.; Yoo, J.-W.; Chun, P.; Moon, H.R. (E)-2-Cyano-3-(substituted phenyl) acrylamide analogs as potent inhibitors of tyrosinase: A linear $\beta$-phenyl- $\alpha, \beta$-unsaturated carbonyl scaffold. Bioorg. Med. Chem. 2015, 23, 7728-7734. [CrossRef] [PubMed]

21. Kang, K.H.; Lee, B.; Son, S.; Yun, H.Y.; Moon, K.M.; Jeong, H.O.; Kim, D.H.; Lee, E.K.; Choi, Y.J.; Do, H.K. (Z)-2-(Benzo [d] thiazol-2-ylamino)-5-(substituted benzylidene) thiazol-4 $(5 \mathrm{H})$-one Derivatives as Novel Tyrosinase Inhibitors. Biol. Pharm. Bull. 2015, 38, 1227-1233. [CrossRef] [PubMed]

22. Bang, E.; Lee, E.K.; Noh, S.G.; Jung, H.J.; Moon, K.M.; Park, M.H.; Park, Y.J.; Hyun, M.K.; Lee, A.K.; Kim, S.J. In vitro and in vivo evidence of tyrosinase inhibitory activity of a synthesized (Z)-5-(3-hydroxy-4-methoxybenzylidene)-2-thioxothiazolidin-4-one (5-HMT). Exp. Dermatol. 2019, 28, 734-737. [CrossRef]

23. Kim, H.R.; Lee, H.J.; Choi, Y.J.; Park, Y.J.; Woo, Y.; Kim, S.J.; Park, M.H.; Lee, H.W.; Chun, P.; Chung, H.Y. Benzylidene-linked thiohydantoin derivatives as inhibitors of tyrosinase and melanogenesis: Importance of the $\beta$-phenyl- $\alpha, \beta$-unsaturated carbonyl functionality. MedChemComm 2014, 5, 1410-1417. [CrossRef]

24. Jung, H.J.; Lee, M.J.; Park, Y.J.; Noh, S.G.; Lee, A.K.; Moon, K.M.; Lee, E.K.; Bang, E.J.; Park, Y.J.; Kim, S.J. A novel synthetic compound,(Z)-5-(3-hydroxy-4-methoxybenzylidene)-2-iminothiazolidin-4-one (MHY773) inhibits mushroom tyrosinase. Biosci. Biotechnol. Biochem. 2018, 82, 759-767. [CrossRef]

25. Jung, H.J.; Lee, A.K.; Park, Y.J.; Lee, S.; Kang, D.; Jung, Y.S.; Chung, H.Y.; Moon, H.R. (2E, 5E)-2, 5-Bis (3-hydroxy-4methoxybenzylidene) cyclopentanone exerts anti-melanogenesis and anti-wrinkle activities in B16F10 melanoma and Hs27 fibroblast cells. Molecules 2018, 23, 1415. [CrossRef]

26. Kim, C.S.; Noh, S.G.; Park, Y.; Kang, D.; Chun, P.; Chung, H.Y.; Jung, H.J.; Moon, H.R. A potent tyrosinase inhibitor,(E)-3-(2, 4-Dihydroxyphenyl)-1-(thiophen-2-yl) prop-2-en-1-one, with anti-melanogenesis properties in $\alpha$-MSH and IBMX-induced B16F10 melanoma cells. Molecules 2018, 23, 2725. [CrossRef] [PubMed]

27. Ullah, S.; Park, Y.; Ikram, M.; Lee, S.; Park, C.; Kang, D.; Yang, J.; Akter, J.; Yoon, S.; Chun, P. Design, synthesis and antimelanogenic effect of cinnamamide derivatives. Bioorg. Med. Chem. 2018, 26, 5672-5681. [CrossRef] [PubMed]

28. Jung, H.J.; Noh, S.G.; Ryu, I.Y.; Park, C.; Lee, J.Y.; Chun, P.; Moon, H.R.; Chung, H.Y. (E)-1-(Furan-2-yl)-(substituted phenyl) prop-2-en-1-one Derivatives as Tyrosinase Inhibitors and Melanogenesis Inhibition: An In Vitro and In Silico Study. Molecules 2020, 25, 5460. [CrossRef]

29. Ullah, S.; Park, C.; Ikram, M.; Kang, D.; Lee, S.; Yang, J.; Park, Y.; Yoon, S.; Chun, P.; Moon, H.R. Tyrosinase inhibition and anti-melanin generation effect of cinnamamide analogues. Bioorg. Chem. 2019, 87, 43-55. [CrossRef] [PubMed]

30. Ullah, S.; Kang, D.; Lee, S.; Ikram, M.; Park, C.; Park, Y.; Yoon, S.; Chun, P.; Moon, H.R. Synthesis of cinnamic amide derivatives and their anti-melanogenic effect in $\alpha$-MSH-stimulated B16F10 melanoma cells. Eur. J. Med. Chem. 2019, 161, 78-92. [CrossRef]

31. Tripathi, A.C.; Gupta, S.J.; Fatima, G.N.; Sonar, P.K.; Verma, A.; Saraf, S.K. 4-Thiazolidinones: The advances continue ... . Eur. J. Med. Chem. 2014, 72, 52-77. [CrossRef]

32. Lesyk, R.B.; Zimenkovsky, B.S. 4-Thiazolidones: Centenarian History, Current Status and Perspectives for Modern Organic and Medicinal Chemistry. Curr. Org. Chem. 2004, 8, 1547-1577. [CrossRef]

33. Tomašić, T.; Peterlin Mašič, L. Rhodanine as a scaffold in drug discovery: A critical review of its biological activities and mechanisms of target modulation. Expert Opin. Drug Discov. 2012, 7, 549-560. [CrossRef] [PubMed]

34. Maddila, S.; Gorle, S.; Jonnalagadda, S.B. Drug screening of rhodanine derivatives for antibacterial activity. Expert Opin. Drug Discov. 2020, 15, 203-229. [CrossRef] [PubMed]

35. Jain, A.K.; Vaidya, A.; Ravichandran, V.; Kashaw, S.K.; Agrawal, R.K. Recent developments and biological activities of thiazolidinone derivatives: A review. Bioorg. Med. Chem. 2012, 20, 3378-3395. [CrossRef] [PubMed]

36. Asati, V.; Mahapatra, D.K.; Bharti, S.K. Thiazolidine-2,4-diones as multi-targeted scaffold in medicinal chemistry: Potential anticancer agents. Eur. J. Med. Chem. 2014, 87, 814-833. [CrossRef]

37. Lesyk, R.; Zimenkovsky, B.; Atamanyuk, D.; Jensen, F.; Kieć-Kononowicz, K.; Gzella, A. Anticancer thiopyrano[2,3-d][1,3]thiazol2-ones with norbornane moiety. Synthesis, cytotoxicity, physico-chemical properties, and computational studies. Bioorg. Med. Chem. 2006, 14, 5230-5240. [CrossRef]

38. Vogeli, U.; Philipsborn, W.V.; Nagarajan, K.; Nair, M.D. C-13-NMR Spectroscopy Part 19. Structures of Addition-Products of Acetylene-Dicarboxylic Acid-Esters with Various Dinucleophiles-Application of C,H-Spin-Coupling Constants. Helv. Chim. Acta 1978, 61, 607-617. [CrossRef]

39. Slominski, A.; Zmijewski, M.A.; Pawelek, J. L-Tyrosine and L-dihydroxyphenylalanine as hormone-like regulators of melanocyte functions. Pigment Cell Melanoma Res. 2012, 25, 14-27. [CrossRef]

40. Slominski, A.; Tobin, D.J.; Shibahara, S.; Wortsman, J. Melanin pigmentation in mammalian skin and its hormonal regulation. Physiol. Rev. 2004, 84, 1155-1228. [CrossRef]

41. Lai, X.; Wichers, H.J.; Soler-Lopez, M.; Dijkstra, B.W. Structure of Human Tyrosinase Related Protein 1 Reveals a Binuclear Zinc Active Site Important for Melanogenesis. Angew. Chem. Int. Ed. 2017, 56, 9812-9815. [CrossRef]

42. The UniProt Consortium. UniProt: The universal protein knowledgebase. Nucleic Acids Res. 2017, 45, D158-D169. [CrossRef]

43. Hyun, S.K.; Lee, W.-H.; Jeong, D.M.; Kim, Y.; Choi, J.S. Inhibitory effects of kurarinol, kuraridinol, and trifolirhizin from Sophora flavescens on tyrosinase and melanin synthesis. Biol. Pharm. Bull. 2008, 31, 154-158. [CrossRef] [PubMed] 
44. Ryu, I.Y.; Choi, I.; Jung, H.J.; Ullah, S.; Choi, H.; Al-Amin, M.; Chun, P.; Moon, H.R. In vitro anti-melanogenic effects of chimeric compounds, 2-(substituted benzylidene)-1,3-indanedione derivatives with a $\beta$-phenyl- $\alpha, \beta$-unsaturated dicarbonyl scaffold. Bioorg. Chem. 2021, 109, 104688. [CrossRef]

45. Hassan, M.; Ashraf, Z.; Abbas, Q.; Raza, H.; Seo, S.-Y. Exploration of novel human tyrosinase inhibitors by molecular modeling, docking and simulation studies. Interdiscip. Sci. Comput. Life Sci. 2018, 10, 68-80. [CrossRef]

46. Saeed, A.; Mahesar, P.A.; Channar, P.A.; Abbas, Q.; Larik, F.A.; Hassan, M.; Raza, H.; Seo, S.-Y. Synthesis, molecular docking studies of coumarinyl-pyrazolinyl substituted thiazoles as non-competitive inhibitors of mushroom tyrosinase. Bioorg. Chem. 2017, 74, 187-196. [CrossRef] [PubMed]

47. Larik, F.A.; Saeed, A.; Channar, P.A.; Muqadar, U.; Abbas, Q.; Hassan, M.; Seo, S.-Y.; Bolte, M. Design, synthesis, kinetic mechanism and molecular docking studies of novel 1-pentanoyl-3-arylthioureas as inhibitors of mushroom tyrosinase and free radical scavengers. Eur. J. Med. Chem. 2017, 141, 273-281. [CrossRef] [PubMed]

48. Friesner, R.A.; Murphy, R.B.; Repasky, M.P.; Frye, L.L.; Greenwood, J.R.; Halgren, T.A.; Sanschagrin, P.C.; Mainz, D.T. Extra precision glide: Docking and scoring incorporating a model of hydrophobic enclosure for protein-ligand complexes. J. Med. Chem. 2006, 49, 6177-6196. [CrossRef] [PubMed]

49. Farid, R.; Day, T.; Friesner, R.A.; Pearlstein, R.A. New insights about HERG blockade obtained from protein modeling, potential energy mapping, and docking studies. Bioorg. Med. Chem. 2006, 14, 3160-3173. [CrossRef]

50. Kim, H.; Roh, H.S.; Kim, J.E.; Park, S.D.; Park, W.H.; Moon, J.-Y. Compound K attenuates stromal cell-derived growth factor 1 (SDF-1)-induced migration of C6 glioma cells. Nutr. Res. Pract. 2016, 10, 259. [CrossRef]

51. Chen, L.G.; Chang, W.L.; Lee, C.J.; Lee, L.T.; Shih, C.M.; Wang, C.C. Melanogenesis inhibition by gallotannins from Chinese galls in B16 mouse melanoma cells. Biol. Pharm. Bull. 2009, 32, 1447-1452. [CrossRef]

52. Bae, S.J.; Ha, Y.M.; Kim, J.A.; Park, J.Y.; Ha, T.K.; Park, D.; Chun, P.; Park, N.H.; Moon, H.R.; Chung, H.Y. A novel synthesized tyrosinase inhibitor: (E)-2-((2,4-dihydroxyphenyl)diazenyl)phenyl 4-methylbenzenesulfonate as an azo-resveratrol analog. Biosci. Biotechnol. Biochem. 2013, 77, 65-72. [CrossRef] [PubMed] 